ISSN: 1130-3743 - eISSN: 2386-5660

DOI: http://dx.doi.org/10.14201/teoredu30273108

\title{
MAESTROS Y DISCÍPULOS. ANATOMÍA DE UNA RELACIÓN
}

\author{
Masters and Disciples. Anatomy of a relationship
}

\section{Maîtres et disciples. Anatomie d'une relation}

\author{
Fernando BÁRCENA ORBE \\ Universidad Complutense de Madrid. Facultad de Educación. Departamento de \\ Teoría e Historia de la Educación. C/ Rector Royo Villanova, 1. 28040 Madrid. \\ fbarcena@ucm.es
}

Fecha de recepción: enero de 2018

Fecha de aceptación: marzo de 2018

RESUMEN

El propósito de este texto es examinar la relación maestro-discípulo como una relación inscrita en un espacio físico e institucional determinado que propicia un vínculo intelectual, ético y existencial. Se trata de una relación de filiación en la que hay lugar tanto a la seducción legítima (incluso erótica) como a la traición declarada: maestros que traicionan a sus discípulos y discípulos que traicionan a sus maestros. Ayudándonos de las evocaciones que algunos discípulos hacen de sus maestros, de reflexiones filosóficas y referencias literarias, se explorará la naturaleza inquietante, enigmática, misteriosa de esta relación a través de las tensiones que produce.

Palabras clave: maestros y discípulos; relación educativa; Eros pedagógico; seducción pedagógica; aula.

\section{SUMMARY}

The main purpose of this text is to examine the master-disciple relationship as a relationship inscribed in a particular physical and institutional space that promotes a 
intellectual, ethical and existencial bond. It is a relationship of filiation in which there is room both for legitimate seduction (even erotic) and declared betrayal: teachers who betray their disciples and disciples who betray their teachers. With the help of evocations that some disciples make of their masters, philosophical reflections and literary references, we will explore the disturbing, enigmatic and mysterious nature of this relationship through the tensions it produces.

Key words: masters and disciples; educational relationship; pedagogical Eros; pedagogical seduction; classroom.

\section{SOMMAIRE}

Le but de ce texte est d'examiner la relation maitre-disciple comme une relation inscrite dans un espace physique et institutionnel particulier qui favorise un lien physique associé à un lien intellectuel, éthique et existentiel. C'est une relation de filiation dans laquelle il y a à la fois une séduction légitime (même érotique) et un possible trahison déclarée: des enseignants qui trahissent leurs disciples et des disciples qui trahissent leurs enseignants. Avec l'aide des évocations que certains disciples font de leurs maîtres, des réflexions philosophiques et des références littéraires, nous explorerons la nature inquiétante, énigmatique et mystérieuse de cette relation à travers les tensions qu'elle produit.

Mots clés: maîtres et disciples; relation éducative; Eros pédagogique; séduction pédagogique; salle de classe.

Para mis amigos, y también maestros, Joan-Carles Mèlich, Jorge Larrosa y Carlos Skliar. Por toda una vida.

\section{INTRODUCCIÓN}

«El buen maestro imparte una explicación satisfactoria; el gran maestro [...] produce inquietud, transmite intranquilidad, invita a pensar» (Sennett, 2009, 17).

Michel de Montaigne decía en uno de sus ensayos -el titulado "La ejercitación»- que "no hay descripción tan ardua como la descripción de uno mismo, ni ciertamente tan útil» (Montaigne, 2007b II, 6, 545; Montaigne, 2007a II, 6, 397). Una vez tomada la decisión de escribirlos, Montaigne se exhibe enteramente en ellos siguiendo la estela del "conócete a ti mismo" (gnoti seauton) socrático. Los Ensayos son, en sí mismos, su skeletos, una singular anatomía en la que aparece, en una sola visión, cada pieza de su ser en el lugar que le corresponde.

La imagen que Montaigne propone es sumamente inspiradora para los propósitos de estas páginas, pues se trata aquí de intentar explorar cierta anatomía, e incluso cierta fisionomía, del encuentro entre profesores y alumnos o, por decirlo más exactamente, entre maestros y discípulos. Recorrida por el tiempo, esta 
relación fue adquiriendo su forma -diríamos, su propio aspecto, su propio rostro-, así como los hábitos que la caracterizan, sus maneras, sus gestos, su estilo propio. Hay toda una estética y toda una poética de la relación entre maestros y discípulos, de la que, como veremos, dan cuenta tanto algunos filósofos como novelistas.

Este asunto es, por lo demás, un tópico que podríamos denominar "clásico» para toda reflexión filosófica de la educación que desee reconocer la importancia del vínculo que une a profesores y alumnos. Insisto en emplear la fórmula "maestro-discípulo", aunque me refiera a la relación entre profesores y alumnos o estudiantes, porque sinceramente pienso que esta categoría sigue siendo inspiradora y ejemplificadora del tipo de relación formativa de la que quiero hablar aquí. Por supuesto, esta relación, que tiene un fuerte valor simbólico, va mucho más allá de lo que acontece en un aula, cuando profesores y alumnos se reúnen para enseñar y estudiar $-y$, en consecuencia, aprender- algunas cosas del mundo que se presentan como asignaturas, disciplinas o materias de estudio. El maestro lo puede ser en cualquier esfera de actividad humana, no solo la estrictamente escolar, como es evidente. Pero es en este ámbito donde adquiere quizá unos rasgos y dimensiones, determinados matices y pliegues que merece la pena examinar con mayor detenimiento.

El decorado en el que habría que inscribir hoy el encuentro entre maestros y discípulos vuelve, sin embargo, sumamente problemática la tarea del análisis que aquí se propone. De hecho, los asuntos que tratarán estas páginas introducen un gesto de lo más inactual dentro de la configuración del discurso pedagógico hoy dominante, inscrito como está en un tipo de organización social que responde a un modelo exclusivamente económico y productivista: el capitalismo cognitivo.

Por decirlo escuetamente, plantear la educación desde la estrechez de la lógica económica es ofrecer una moneda falsa, pues el acto educativo tiene que ver con el don, dicho en términos de Jacques Derrida: «Para que haya don, es preciso que el donatario no devuelva, ni amortice, ni salde su deuda, ni la liquide, es preciso que no se meta en ningún contrato» (Derrida, 1995, 22). Para que el don pueda ofrecerse tiene que aparecer lo sorprendente del regalo: una herencia es realmente grande cuando no se muestra la mano del difunto que lega. La educación no consiste en llenar una vasija vacía; más bien se trata de proporcionar un buen material capaz de provocar un incendio en la mente del discípulo, aunque hay que tener mucho cuidado con él. Pues lo que, en una hora de clase, en el transcurso de un curso, se promueve, es, ni más ni menos, que un cierto cultivo de sí. El aula permite que profesores y alumnos estudien juntos, y con ello se dan la oportunidad para que cada uno descubra el tipo de ser humano que quiere llegar a ser. No interactuamos con máquinas, sino con sujetos dotados de una biografía. Nuestros estudiantes no son objetos para modelar ni fabricar, y por eso no podemos exigir a la educación ni garantías, ni predicciones, ni seguridades, más allá de lo razonable. El propósito del acto educativo no es, de manera ninguna, conseguir un trabajo ni habilitarse para funcionar en el mercado, sino transformar una existencia. La escuela, en fin, no es una especie de extensión ni de lo social, ni del mercado, ni 
de la familia. Es un "lugar aparte» donde se inicia a los alumnos en el mundo en que van a vivir y donde se ejercitan en el tiempo libre, que es el tiempo verdaderamente humano.

Una imagen quizá un poco extrema, pero que define bastante bien el contexto al que me estoy refiriendo, la ofrece George Perec en su novela W, o el recuerdo de la infancia. Este libro incluye dos clases de relatos paralelos. El primero es la reescritura de una historia ficticia olvidada, titulada $W$, y el segundo habla de la misteriosa isla de W, ubicada en el archipiélago de Tierra del Fuego, que vive en torno a la exaltación del deporte, la competición y la victoria. Los premios conllevan títulos honoríficos y otra clase de beneficios, mientras que a los derrotados se les castiga con vejaciones que, en casos aislados, pueden incluso conducir a la muerte: "Esto es lo que hay, y eso es todo", dirá el narrador:

Las competiciones cotidianas, las victorias o las derrotas. Hay que luchar para vivir. No hay otra elección. No existe alternativa alguna. No cabe taparse los ojos, no cabe rehusar. No hay recurso ni piedad, de nadie cabe esperar salvación [...] Pero incluso los atletas más ancianos, incluso los veteranos seniles que salen a hacer el payaso en las pistas entre prueba y prueba y a quienes la multitud jocosa alienta, incluso ésos creen todavía que hay otra cosa, que el cielo puede ser más azul, la ropa mejor; la ley menos dura, creen que el mérito será recompensado, creen que la victoria les sonreirá y que será hermosa (Perec, 2014, 177-178).

En nombre de la formación de profesionales competentes, expertos y especialistas; en nombre del progreso y de los procesos de internacionalización de nuestras instituciones superiores de formación; en nombre del sostenimiento de los campus universitarios de "excelencia" -que se gobiernan como empresas privadas donde lo único que cuenta es acumular dinero, da igual el coste-, hemos liquidado lo mejor del espíritu universitario, hemos defraudado a las nuevas generaciones haciendo lo peor que se puede hacer con los jóvenes: mentirles, al prometerles algo que nunca les podríamos dar, como por ejemplo trabajo; se han confundido los fines de la formación con los del mercado; hemos infantilizado a nuestros estudiantes, les hemos alumnizado en nombre de la llamada sociedad del aprendizaje; hemos postsecundarizado la universidad y convertido nuestros centros de educación superior en escuelas sin profundidad en la formación que impartimos; hemos invadido los espacios, que no hace mucho todavía servían para mantener conversaciones intelectualmente inquietantes en torno a una gran obra, con grupos de investigación absolutamente burocratizados que en general invierten el tiempo en no hacer nada que merezca realmente la pena, y solo porque al final les piden un informe de las actividades realizadas. Más o menos, y quizá exagerando los rasgos, esta es la situación. Podrían añadirse más elementos. Pero basta con lo dicho para decir que ser profesor o profesora no es desempeñar sin más un puesto de trabajo, sino profesar una vocación (Schlanger, 1997; Larrosa, 2018, 39-64).

En el marco que acabo de referir, la idea de una presencia real entre profesores y alumnos, entre maestros y discípulos, parece haber perdido ya sus antiguas 
significaciones. Importa hoy menos el impacto formativo que tiene, para una subjetividad en transformación, una relación como esta que el hecho de que, sea cual sea el tipo de relación que se establezca, las nuevas generaciones aprendan. Dentro de la llamada sociedad del aprendizaje, en el contexto del capitalismo cognitivo, la figura del alumno que indudablemente destaca es la de un "alumno funcional»y "emprendedor de sí mismo»: "Igual que la empresa toma el relevo de la fábrica, la formación permanente tiende a sustituir la escuela, y el control continuo tiende a sustituir al examen. Lo que es el medio más seguro para poner la escuela en manos de la empresa» (Deleuze, 1995, 280). Sabemos que se pueden aprender muchas cosas, y más rápidamente, al margen de la mediación de profesores y maestros y, como han sugerido algunos filósofos de la educación contemporáneos, el nuevo lenguaje del aprender ha sustituido a un lenguaje de la educación y para la educación. Lo que tal vez no se quiere admitir es que no existe una relación directa ni evidente entre lo que un profesor hace y cómo el alumno aprende. Entre el enseñar y el aprender la distancia es infinita.

La imagen que desea ofrecerse en este ensayo sobre la relación maestrodiscípulo está fuertemente inspirada en determinadas lecturas de la filosofía griega, dentro de la cual la filosofía constituía una forma de vida elegida y, en sí misma, una forma de educación que comprometía un determinado encuentro entre el filósofo y sus discípulos. Desde antiguo, el establecimiento de alguna clase de relación entre maestros y discípulos, entre adultos y jóvenes, constituyó la vía a través de la cual el pensamiento se encaminaba hacia las verdades o el conocimiento que anhelaba encontrarse. Desde este punto de vista, resultaba impensable una separación entre la búsqueda amorosa de la sabiduría, que la filosofía encarnaba, y la palabra viva que se intercambia con los discípulos. A partir de Kant, el filósofo es predominantemente un profesor; y Hegel, un filósofo que habla desde la altura de una cátedra. Que esto haya sido así no deja de generar algunas dificultades teóricas, pues asimilado a un saber a transmitir con autoridad, pero desde la más grande neutralidad, la filosofía corre el riesgo de no preocuparse ya de las relaciones persona a persona: el filósofo transmite una filosofía ya establecida, pero no su pensamiento vivo, sus interrogantes, sus preguntas y sus dudas. El filósofo académico exige a sus aprendices, entonces, que comprendan la filosofía transmitida sin cuestionarse necesariamente sus pretensiones de verdad y su relación de sentido con sus propias vidas. En suma: cualquier cuestión existencial quedaría marginada como algo impertinente ante la soberanía de la abstracción conceptual (Chalier, 1996, 118). Será Nietzsche quien, como ya había formulado antes Schopenhauer (2009, 161-223) en sus críticas a la filosofía universitaria y académica, que el propio Hegel según aquel encarnaba, insista en el hecho de que "la relevancia que tiene un filósofo para mí está en función directa de su capacidad para ofrecer un ejemplo [...] Pero el ejemplo deber ser dado mediante la vida visible y no sólo a través de libros, esto es, a la manera como enseñaban los filósofos griegos» (Nietzsche, 1996, 151). Para el propio Nietzsche, durante un tiempo, será el propio Schopenhauer ese filósofo-educador, ese maestro que aspira a mantenerse separado de la sociedad y del Estado. 
Lo que se va a proponer pensar, entonces, pretende recuperar ese otro modo según el cual, como ocurría con la filosofía griega antigua, enseñar, transmitir, establecer un encuentro con los discípulos, requiere tener que formularse cuestiones de sentido y de carácter existencial para una joven alma en formación. Teniendo en cuenta esto, se planteará la relación entre maestros y discípulos como un encuentro inscrito en un determinado espacio físico e institucional que propicia un lazo físico que deviene también un lazo espiritual. Se trata de una relación elegida (y de filiación) que compone una trama en la que hay lugar tanto para la seducción legítima (incluso erótica, ya veremos en qué sentido) como para la traición declarada: maestros que traicionan a sus discípulos y discípulos que traicionan a sus maestros. Así que, en lo que sigue, ayudándonos de las evocaciones que algunos discípulos hacen de sus maestros, de reflexiones filosóficas y referencias literarias, se explorará la naturaleza inquietante, enigmática, misteriosa, de esta relación a través de las tensiones existenciales que produce. Como escribió Georges Steiner: "Raras veces nos paramos a considerar las maravillas de la transmisión, los recursos de la falsedad, lo que yo llamaría - a falta de una definición más precisa y material- el misterio que le es inherente» (Steiner, 2003, 11). Es de ese "misterio» del que queremos hablar aquí.

\section{ENCONTRARSE CON LOS MAESTROS}

En mis tiempos de estudiante universitario me encontré un pequeño libro que, a su manera, decía cosas como lo que acabo de escribir en el epígrafe anterior. Leí ese libro en su traducción al castellano y su título -¿Para qué los profesores?- me llamó la atención de inmediato. Su autor era Georges Gusdorf (1912-2000), filósofo e historiador de las ideas que procedía de una familia judeo-alemana y que estuvo cinco años en un campo de prisioneros del ejército alemán en Lübeck. Entre otras obras, escribió la monumental Les sciences humaines et la pensée occidentale, en 14 volúmenes. Gusdorf fue alumno de Gaston Bachelard en la École normale supérieure (ENS) de París, como también lo fue de Alain, Lévy-Bruhl, Piaget y Mauss, e hizo su carrera académica en la Sorbona, cuya tesis doctoral dirigió Léon Brunschvicg. En los años 1950, preparó a agregados en la ENS, como sucesor de Maurice Merleau-Ponty. Fue maestro de Althusser y de Michel Foucault. El libro de Gusdorf que leí en esa época está hoy agotadoํㅡㄹ tanto en francés como en castellano, pero es una obra que, en mi opinión, no debería faltar en la biblioteca (si es que todavía se hacen esas cosas en la Universidad de hoy) de un estudiante de pedagogía y todo aquel o aquella que han elegido el oficio de profesor.

1. En estos momentos se prepara una nueva y actualizada traducción, a cargo de Fernando Fuentes Megías, y será publicado en la editorial Miño \& Dávila, con un estudio introductorio a mi cargo. Quiero aquí expresar mi agradecimiento tanto al traductor - no me cabe duda de que esta nueva traducción será ejemplar- como al editor, Gerardo Miño, por haber aceptado el reto. 
La lectura de ese libro, que contribuyó a la formación de muchos de quienes a la altura de comienzos de los años 80 iniciábamos nuestra andadura académica en filosofía de la educación, mantiene hoy plena vigencia, aunque probablemente hay en él algunos aspectos que tienen que ver muy coyunturalmente con las características de la época en la que fue escrito. El fondo permanece, sin embargo, intacto; y es precisamente ese trasfondo lo que ha permanecido desde hace más de tres décadas en mí haciendo su trabajo. Este texto le debe mucho a aquella antigua experiencia lectora, que me enseñó que, si es cierto que las diferentes maneras de pensar se traducen en distintas maneras de escribir, también lo es que las diferentes maneras de profesar deben traducirse en distintas formas de ser profesor.

Al final de su libro, Gusdorf dice algo bastante extraño, que solo se entiende tras haberlo leído enteramente:

El magisterio es un misterio. La relación del maestro con el alumno es un diálogo
sin comunicación, una comunicación indirecta y sin plenitud, una fuga cuya solu-
ción y resolución será perpetuamente rechazada. Bergson, ante sus más fieles dis-
cípulos, pensaba en voz alta y completamente solo [...] El secreto del magisterio es
que el maestro no existe [...] No hay maestros, y los maestros menos auténticos son
indudablemente aquellos que desde las alturas de una autoridad prestada presu-
men de maestros, intentando abusar de la confianza de los demás y engañándose
sobre todo a sí mismos (Gusdorf, 1977, 297-298).

Es una de las tareas más complejas la de ser profesor. Pues el que enseña tiene mucho más que aprender que el alumno, o quizá algo que a este no le corresponde: debe dejar que el otro aprenda por su cuenta. Más aún: de lo que el profesor enseña no cabe inferir (como de una causa su efecto correspondiente) el aprender, sino el motivo, el movimiento, el inicio que empuja al discípulo a buscar un saber del que terminará enamorándose. Entonces, ese profesor, ese maestro, se convierte en un mediador del deseo de saber del otro, no de su deseo de aprender.

Las palabras de Gusdorf destilan un gesto de pudor y modestia; virtudes necesarias, sin duda, hablando del magisterio. Pero dejemos ahora el misterio del que habla Gusdorf ahí mismo, sin explicarlo más. Tal vez sea lo mejor que podamos hacer para animar a la lectura de este hermoso libro.

Una cosa es ser profesor y otra muy diferente ser un maestro. Estas dos figuras no siempre coinciden en el mismo ser ni confluyen en la misma estructura de una personalidad. A menudo, quienes nos dedicamos a la enseñanza solo somos eso: profesores y profesoras. Llegar a ser un maestro es algo que no podemos elegir. Y el asunto no reside en aspirar o no a ser un maestro. En todo caso, la elección le corresponde al alumno, que en el mismo instante que escoge a alguno de sus profesores como "maestro" lo instituye como tal transformándose él mismo en su discípulo. Entonces, "maestro» deviene una categoría existencial, en la condición recién adquirida de discípulo, por aquel que ha lo ha elegido. Es, pues, el discípulo quien -para bien o para mal- erige en cuanto tal al maestro: 
El discípulo sólo existe, pues, para el maestro, que es mediador de existencias. Pero el mismo maestro no existe más que para el discípulo. Hay una vocación del maestro al magisterio del que únicamente el testimonio del discípulo puede aportarle la revelación. Es normal que el maestro esté inquieto y que dude de su certeza. Ningún ser humano es completamente digno de soportar la aplastante carga de la verdad [...]. Es necesario, para que salga de su reserva, que el discípulo le dirija su requerimiento (Gusdorf, 1977, 227).

Pero nuestros maestros no son solo los seres humanos que nos enseñaron en el ámbito escolar. Muy a menudo, en la esfera intelectual, y en otros órdenes, son aquellos que al leer y frecuentar sus obras y creaciones nos influyeron y ayudaron a cambiar el curso de nuestras existencias. Son quienes el azar de la vida nos puso delante y nos influyeron. En filosofía, en la literatura y en la poesía, en general en las artes, en la pintura, la música y las ciencias, nuestros maestros son esos perfectos desconocidos que aprendimos a amar en la distancia del tiempo, a través de las obras que nos dejaron y a las que accedimos.

De todos modos, entre los recuerdos más entrañables que un ser humano tiene, los escolares revisten una especial importancia en nuestras biografías y, de modo preferente, los que evocan el encuentro con los maestros. La relación maestro-discípulo ha inspirado testimonios de todo tipo, dando lugar a importantes creaciones filosóficas, literarias y también pedagógicas. Los interrogantes son abundantes: ¿Por qué los maestros? ¿Por qué nos encontramos con ellos? ¿Qué cosas pasan en ese encuentro? ¿En qué consiste nuestra necesidad de maestros? ¿Qué legitima el derecho a la transmisión de los saberes desde un lugar a otro de la escala generacional? ¿Dónde se sostiene la autoridad de los profesores y maestros: en el ejemplo que ofrecen? ¿En el poder que ostentan? ¿Qué papel desempeña, y qué caminos recorre, el poder de influencia, moral e intelectual, de los maestros sobre sus discípulos? ¿Qué pueden decirnos los filósofos, los novelistas, los pedagogos sobre estas cuestiones?

Estas preguntas no esconden ningún estado de ánimo melancólico, ninguna clase de queja acerca de la ausencia o no de grandes maestros. Simplemente tratan de poner el acento en la evidencia de que existe un tipo de relación en la que hay cosas que tal vez podrían pasar y que hoy ya no ocurren, o no interesa que acontezcan, y esas cosas que ya no pasan no tienen que ver con la calidad de los aprendizajes, sino con la formación de una subjetividad: enseñar a alguien es, ni más ni menos, ayudarle a convertirse en sujeto. No se trata de instruirle para que se identifique con el papel que previamente la sociedad le ha asignado, sino de contribuir a que encuentre su propia forma: "La relación con el maestro, que en un principio parece ligarme a otro, oculta una relación más importante conmigo mismo. Por mediación de una revelación exterior me dirijo a una conciencia mayor de mi ser propio» (Gusdorf, 1977, 91). Acaso la relación pedagógica tenga que ver, entonces, con cierta clase de mediación del deseo, por decirlo con René Girard (1985).

Algunas novelas de la literatura española dan cuenta de ese poder de influencia en la existencia de un joven por parte de un maestro al que se ha elegido; por 
ejemplo, en La voluntad, la primera novela de Azorín. Toda la primera parte es algo así como una puesta en clave de ficción del ensayo de Nietzsche "Schopenhauer como educador»:

El maestro va y viene ante Azorín en sus peripatéticos discursos. Habla resueltamente. A través de la palabra enérgica, pesimista, desoladora, colérica, iracunda -en extraño contraste con su beata calva y plácida sonrisa- el maestro extiende ante los ojos del discípulo hórrido cuadro de todas las miserias, de todas las insanias, de todas las cobardías de la humanidad claudicante. La multitud le exaspera; odio profundo, odio tal vez rezago de lejanos despechos, le impulsa fieramente contra la frivolidad de las muchedumbres veleidosas. [...] Y a lo largo de la estancia recargada de libros, nervioso, irascible, enardecido, va y viene mientras sus frases cálidas vuelan a las alturas de una sutil y deprimente metafísica, o descienden flageladoras sobre las realidades de la política venal y de la literatura vergonzante. Azorín escucha al maestro. Honda tristeza satura su espíritu en este silencioso anochecer de invierno. Yuste pasea. A lo lejos suenan las campanas del santuario. Los opacos tableros de piedra palidecen. El maestro se detiene un momento ante Azorín y dice: -Todo pasa, Azorín; todo cambia y perece. Y la substancia universal -misteriosa, incognoscible, inexorable- perdura (Azorín, 1989, 72).

El personaje de la novela -Azorín- no parece aceptar la derrota metafísica del pesimista Schopenhauer y se rebela contra su tiempo. Ha de refugiarse en su yo íntimo, que será su único asidero, mientras escucha, atento, a su maestro. El trato con el maestro va dando forma al discípulo y agudiza más su inquietud:

Azorín va y viene de su cuarto a la biblioteca. Y esta ocupación es plausible. Azorín lee en pintoresco revoltijo novelas, sociología, crítica, viajes, historia, teatro, teología, versos. Y esto es doblemente laudable. Él no tiene criterio fijo: lo ama todo, lo busca todo. Es un espíritu ávido y curioso; y en esta soledad de la vida provinciana, su pasión es la lectura y su único trato el trato del maestro. Yuste va insensiblemente moldeando este espíritu sobre el suyo (Azorín, 1989, 94).

Si el maestro Yecla agudiza en el discípulo cierta inquietud, cierta tristeza y melancolía, el Flaubert tratará de arrancar de esos estados de ánimo a su discípula. En una carta del 18 de mayo de 1857, Flaubert responde a las inquietudes de su amiga Marie-Leroyer de Chantepie, que en una epístola anterior se había quejado del estado del mundo debido a las múltiples injusticias y sufrimientos que percibía. Flaubert le dice: «Se rebela usted contra las injusticias del mundo, contra su bajeza, su tiranía y contra toda la infamia y fetidez de la existencia. ¿Las conoce bien? ¿Lo ha estudiado todo? ¿Es usted Dios?» (Flaubert, 2009, 106). Flaubert le prescribe, entonces, su propia receta, haciéndole notar que, como ella quizá carece del hábito del «amor a la contemplación», tal vez sea conveniente ponerse a estudiar: «Tómese la vida, las pasiones y a usted misma como un motivo para el ejercicio intelectual", le dice. Si queremos vivir, 
hay que renunciar a tener una idea tan clara de todo. La bumanidad es así, no se trata de cambiarla, sino de conocerla. No piense tanto en usted. Abandone la esperanza de una solución [...] En el ardor del estudio hay alegrías a la medida de las almas nobles. A través del pensamiento, únase a sus hermanos de hace tres mil años; recoja todos sus sufrimientos, todos sus sueños, y sentirá cómo se ensanchan, al mismo tiempo, el corazón y la inteligencia [...] Haga grandes lecturas. Adopte un plan de estudios que sea riguroso y sostenido [...] Impóngase un trabajo regular y fatigoso. Lea a los grandes maestros y trate de captar su conducta, de acercarse a su alma. De ese estudio saldrá deslumbrada y alegre (Flaubert, 2009, 106-107).

Flaubert le propone a su amiga un régimen de estudio, y es ese régimen el medio a través del cual su amiga quizá pueda encontrar otro modo de ser ella misma y aprender a cuidar de sí. El escritor-maestro le está diciendo que se atreva a la contemplación, al pensamiento, a la vida intelectual. Anima a que establezca una distancia estética con el mundo que tanto daño le hace mediante un estado de ánimo diferente: el del estudio. Le dice que es mejor conocer el mundo que pretender cambiarlo. Le está diciendo, en fin, que lleve una vida estudiosa, haciéndole notar que ese estudio es un cierto ejercicio intelectual, un cierto ejercicio "espiritual», un poco como los griegos entendieron que era la actividad del filósofo enamorado de la sabiduría: es decir, una forma de vida. Como escribe Gusdorf: "La cuestión no es aprender muchas cosas, sino conocerse a sí mismo y ejercitarse en la maestría cualquiera que sea el terreno particular de ejercicio que sea escogido» (Gusdorf, 1977, 73).

Encontrarse con un maestro, con un profesor, hombre o mujer, a quien hemos elegimos como tal, significa encontrarse con una vocación, y es intentar ofrecer una respuesta a la pregunta ¿qué tipo de vida quiero llevar? Es encontrarse, para el caso y el espacio que nos ocupa -las instituciones de formación- con un mundo otro, un mundo que ha sido leído, escrito, interpretado por nuestros maestros. Pues un maestro arrastra consigo una biblioteca, unos modos de leer, de escribir, de pensar y de mirar. Y al acceder a ese mundo lo que a veces acontece es que el discípulo, sorprendente y misteriosamente, se encuentra consigo mismo, pero viéndose de otra manera.

\section{EVOCACIONES: LA MEMORIA DE LOS DISCÍPULOS}

El que va a enseñar aprende la lección más profunda, mientras que quienes van a aprender no aprenden nada (J. M. Coetzee, Desgracia).

La relación discipular es una dimensión fundamental del vínculo intelectual (ético, estético, poético, político) entre dos seres humanos. Este vínculo está atestado de referencias tanto filosóficas como literarias, en las que destaca el recuerdo agradecido.

En los textos que los discípulos escribirán en su momento, a menudo los maestros se hallan presentes, al comienzo de los mismos, bajo dedicatorias del tipo 
"A mi maestro", así como en las evocaciones dirigidas "Al lector», o en explícitos "Agradecimientos". Tanto en las cartas de recomendación, como en las lecciones inaugurales, en los aniversarios, las jubilaciones, en las ceremonias fúnebres y otros homenajes al maestro perdido, esta clase de textos introducen una necesaria dimensión subjetiva y ponen en evidencia que un maestro ha hablado personalmente al discípulo y que este ha recibido íntimamente su palabra como un inapreciable regalo en su formación. Naturalmente, los textos que los discípulos escriben son reconstrucciones a posteriori que aspiran a una puesta en orden de los hechos realmente acontecidos y que definieron una antigua relación discipular. Probablemente también existan omisiones, simplificaciones y distorsiones más o menos deliberadas (Waquet, 2008, 51-52). Exploremos algunas de estas evocaciones.

La primera de ellas es del filósofo francés Gilles Deleuze, que en el año 1964 consagra a Jean-Paul Sartre su propio homenaje en una corta nota, que comienza de este modo:

Triste generación la que carece de maestros. Nuestros maestros no son únicamente los profesores públicos, aunque tengamos gran necesidad de profesores. En el momento en que alcanzamos la mayoría de edad, nuestros son aquellos que nos impresionan con una novedad mayor, los que saben inventar una técnica artística o literaria y encontrar la forma de pensar correspondiente a nuestra modernidad, es decir, tanto a nuestras dificultades como a nuestros difusos entusiasmos (Deleuze, 1964, 8).

La fórmula de Deleuze - «Tristeza de generaciones sin maestros»- es de lo más extraña, por varias razones. Primero, por la distancia que separa el pensamiento sartriano del pensamiento de Deleuze, debido a su orientación claramente antifenomenológica. Esta primera razón es fácil de disipar, en la medida que es precisamente responsabilidad de los maestros animar a sus discípulos a que se separen de ellos para que adopten sus propios caminos. La segunda razón tiene que ver con la heterogeneidad de la afirmación de Deleuze con respecto a su propia filosofía, que deja en verdad poco espacio para un elogio a los maestros en el sentido de expertos o especialistas. En realidad, a Deleuze le llamaban más la atención las flechas tiradas al azar que la continuidad de las tradiciones, es decir, una especie de relación indisciplinada con la tradición y el pasado. Por último, está la cuestión de la tristeza; ¿de qué género de tristeza se hace eco Deleuze? ¿Qué generación es la que se lamenta y llora? La suya no, pues tenía a Sartre como figura tutelar. Tal vez se trata de la generación posterior, la generación de la década de los años 1970, quizá la nuestra. Pero entonces, esa generación que lamenta la ausencia de maestros, ¿a quiénes deben responsabilizar del vacío que sienten? ¿A quienes, como el propio Deleuze, que sí dispuso de ellos, parecen no querer serlo de ninguna forma? (Artières y Potte-Bonneville, 2012, 49).

Los mismos gestos que aparecen en Deleuze los encontramos en las páginas finales de El orden del discurso de Michel Foucault, su lección inaugural en el Collège de France. Foucault se refiere allí a la figura tutelar de Jean Hyppolite, 
traductor y comentador al francés de Hegel, y que había fallecido dos años antes de la elección de Foucault como profesor de aquella prestigiosa institución. Foucault alude a Hyppolite como esa voz en la cual él mismo querría haberse ocultado subrepticiamente, como dice al final de su lección: «Ahora comprendo mejor por qué experimentaba tanta dificultad al comenzar antes. Sé bien cuál era la voz que habría querido que me precediera, que me llevara, que me invitara a hablar y que se introdujera en mi discurso" (Foucault, 2015, II, 259). Lo que en el futuro hará Foucault, lo que en ese mismo instante ya está haciendo al pronunciar su discurso, se lo debe a él, al maestro: "Porque he tomado de él, sin duda, el sentido y la posibilidad de lo que hago [...] Es hacia él, hacia su falta -en la que experimento a la vez su ausencia y mi propia carencia- hacia donde se cruzan las cuestiones que me planteo actualmente» (Foucault, 2015, II, 259).

Al igual que en Deleuze, también la orientación de Foucault se aleja de Hyppolite: claramente su pensamiento es antihegeliano; asimismo, la reverencia que ofrece del desaparecido antecesor en la cátedra que se dispone a ocupar contradice el tema que recorre la propia lección inaugural que está pronunciando (Foucault propone allí desvelar los mecanismos anónimos de producción del discurso); por último, en el mismo gesto en el que Foucault agradece que sea Hyppolite la condición de posibilidad de su propio discurso también se encuentra el deseo, expresado por él, de no ser quien comience nada, es decir, de ser "le point de sa disparition posible». La pregunta resulta inevitable: ¿Cómo podemos nosotros, las generaciones posteriores, ser los alumnos de quienes de forma ninguna quisieron ser nuestros maestros? ¿Cómo colmar este vacío?

A veces, los discípulos saben captar, en los relatos que hacen de sus maestros, la intimidad que estos establecieron con aquello que hacen y llegan a encarnar. $\mathrm{Y}$ es esa intimidad, esa encarnadura, la que les transmiten precisamente, como en esta evocación que Michel Onfray hace de su maestro de filosofía antigua, Lucien Jerphagnon:

En el inicio del curso sobre Lucrecio mi viejo maestro tomó sabiamente la decisión de agradecer a los que vendrían a verlo, y de agradecer más vivamente aún a aquellos que harían economía de visitas y de relaciones. Esta 'puesta a distancia' tenía la intención de solidificar las veleidades, endurecer las tentaciones. Su antiguo volumen bilingüe tenía una constelación de marcas de todos los colores: negro, rojo, violeta o azul. La intimidad que había entre las páginas y el viejo profesor revelaba las horas de meditación, de traducción. Al mismo tiempo, yo descubría hasta qué punto podía ser preciosa la relación de una persona con un libro, de un hombre y un pensamiento con un texto que no fuera la Biblia o cualquier breviario. La tapa de su libro se había despegado y muchas páginas de aquel papel amarillento y suave al tacto se esparcían bajo los dedos pues la encuadernación se había aflojado mucho tiempo antes. Junto al volumen, el profesor colocaba un gran reloj de bolsillo, probablemente con su cadena, y la madera del escritorio, que hacía las veces de caja de resonancia de un instrumento musical amplificaba el tic tac. La pipa y el tabaco completaban el sistema de objetos, y como la habitación era de dimensiones pequeñas, podía olerse el perfume azucarado, de miel y frutos exóticos, dejado 
por sus bocanadas. Las manos del profesor iban del reloj al libro, de la pipa a las hojas dactilografiadas de su curso, con frecuencia inútiles puesto que se trataba de mostrar la elaboración de un pensamiento, ejercicio que no suele prestarse a la codificación previa. Lucrecio se transformaba entonces en un contemporáneo, y sus palabras parecían salir como un eco y encontrar su actualidad en un lenguaje completamente moderno y cotidiano (Onfray, 2002, 17).

Otro tipo de evocación es la que se refiere a la falta de grandeza de profesores y enseñantes, como la que nos proporciona Peter Handke en Ensayo sobre el cansancio. Al recordar sus años de estudiante, declara:

Por regla general, no era tanto el aire enrarecido y el apiñamiento forzado de cientos de estudiantes como la falta de interés que los que daban las clases mostraban por la materia, una materia que en realidad debería ser la suya. Nunca más he vuelto a encontrarme con hombres menos poseídos por lo que llevaban entre manos que aquellos catedráticos y profesores de Universidad; cualquier empleado de banco, sí, cualquiera, contando los billetes, unos billetes que además no eran suyos, cualquier obrero que estuviera asfaltando una calle, en el espacio caliente que había entre el sol, arriba, y el hervor del alquitrán, abajo, daba la impresión de estar más en lo que hacían (Handke, 1989, 13).

Estar poseídos por lo que enseñamos; estar ahí, plenamente presentes, en eso que transmitimos. Nunca se subrayará bastante la importancia de esa posesión y de esa presencia. Y es que "no se puede entrar en clase sin una buena preparación. No se puede hablar al alumno sin amar lo que se enseña. Una pedagogía rutinaria acaba por matar cualquier forma de interés» (Ordine, 2017, 18). La mejor literatura está repleta de referencias a esta tristeza de la que hablamos, y a esta dejación de profesores y educadores. En su evocación, Handke no se queja de la ausencia ni de didácticas ni de metodologías pedagógicas. Se queja de la falta de pasión de sus profesores. De su falta de amor por lo que hacían y enseñaban.

En Maestros antiguos, el escritor austriaco Thomas Bernhard también ofrece una amarga evocación de los profesores como artífices de la destrucción de jóvenes vidas. Reser, que monologa a lo largo de todo el relato -un musicólogo y crítico literario del diario The Times-, dice:

Al fin y al cabo, los profesores no son sólo, en lo que al arte se refiere, los obstaculizadores y aniquiladores, los profesores, al fin y al cabo, han sido siempre a fin de cuentas los obstaculizadores de la vida y de la existencia, en lugar de enseñar a los jóvenes la vida, de descifrarles la vida, de hacer de la vida para ellos una riqueza realmente inagotable por su propia naturaleza, la matan en ellos (Bernhard, 1987, 35).

El texto de Bernhard -se trata de una ficción, conviene no olvidarlo- sin duda enojará a muchos. Enojará la amargura que destila y la contundencia de sus afirmaciones. Pero no todo es aflicción y pesadumbre. La relación maestro-discípulo es una dimensión fundamental del mundo humano. Así fue, por ejemplo, para 
Albert Camus. Recordemos la bellísima carta que el discípulo Camus escribió el 19 de noviembre de 1957, tras recibir el Premio Nobel de Literatura, a su maestro Louis Germain:

Querido señor Germain:

He esperado a que se apagase un poco el ruido que me ha rodeado todos estos días antes de hablarle de todo corazón. He recibido un honor demasiado grande, que no he buscado ni pedido. Pero cuando supe la noticia, pensé primero en mi madre y después en usted. Sin usted, la mano afectuosa que tendió al pobre niñito que era yo, sin su enseñanza y ejemplo, no hubiese sucedido nada de esto. No es que dé demasiada importancia a un honor de este tipo. Pero ofrece por lo menos la oportunidad de decirle lo que usted ha sido y sigue siendo para mí, y le puedo asegurar que sus esfuerzos, su trabajo y el corazón generoso que usted puso continúan siempre vivos en uno de sus pequeños discípulos, que, a pesar de los años, no ha dejado de ser su alumno agradecido. Le mando un abrazo de todo corazón. Albert Camus (Camus, 2003, 295).

En su respuesta, Germain comienza su carta de este modo: "Mi pequeño Albert». Y prosigue de este modo:

El pedagogo que quiere desempeñar concienzudamente su oficio no descuida ninguna ocasión para conocer a sus alumnos, sus hijos, y éstas se presentan constantemente. Una respuesta, un gesto, una mirada son ampliamente reveladores. Creo conocer bien al simpático hombrecito que eras y el niño, muy a menudo, contiene en germen al hombre que llegará a ser. El placer de estar en clase resplandecía en toda tu persona. Tu cara expresaba optimismo. [...] He visto la lista en constante aumento de las obras que te están dedicadas o que hablan de ti. Y es para mí una satisfacción muy grande comprobar que tu celebridad (es la pura verdad) no se te ha subido a la cabeza. Sigues siendo Camus: bravo (Camus, 2003, 296).

Uno no puede sino conmoverse profundamente leyendo ambas epístolas. El maestro Germain aparecerá, como no podía ser de otro modo, en la última e inacabada novela de Camus, El primer hombre (será allí el maestro Bernard), en un delicioso capítulo donde se recrea la escuela a la que el pequeño Albert asistía; él, como otros muchos de sus compañeros de aula, huérfanos de padre (todos ellos muertos en la Primera Guerra Mundial). Allí leemos que la escuela no solo ofrecía a los alumnos una evasión de la vida de la familia. Había algo más, dice Camus: "En la clase del señor Bernard por lo menos, la escuela alimentaba en ellos un hambre más esencial todavía para el niño que para el hombre, que es el hambre de descubrir [...] En la clase del señor Germain -nótese aquí que el nombre ya ha cambiado-, sentían por primera vez que existían y que eran objeto de la más alta consideración: se les juzgaba dignos de descubrir el mundo" (Camus, 2008, 830). El maestro no solo les enseñaba lo que debía enseñarles: además les acogía con la máxima simplicidad en su vida personal; la vivía con ellos. Entre el maestro y los 
alumnos se establecía un lazo de filiación. Mutuamente se escogían, se elegían. Él era un maestro y ejercerá con ellos, puesto que la mayoría de ellos no tenían ya padre, una paternidad vicaria.

Igual que el personaje principal (Tom Crick) de la novela Waterland (El país del agua), de Graham Swift, que es un profesor de historia cuya disciplina tiene más bien poco éxito entre sus alumnos. En vez de batallas, fechas y cosas así, Crick habla de sí mismo, de su historia, del pasado y de la lucha de su familia contra los pantanosos Fens ingleses. Su mujer ha cambiado el amor a su marido por el amor a Dios. La pregunta ¿sirve para algo la historia? se repetirá constantemente a lo largo de la novela, y hará que uno de sus alumnos más críticos (Pierce), diga que lo que importa «es el aquí y ahora. Y no el pasado. El aquí y ahora, y el futuro». Pero Crick ama su disciplina; además la encarna: «Él mismo no era más que un fragmento de lo que enseñaba. Dicho con otras palabras, el tipo se flipó, se volvió majara...” (Swift, 1992, 14-15). Cuando habla a sus alumnos, les dice: "Niños. Niños que vais a heredar el mundo. Niños (porque aunque tuvierais quince, dieciséis o diecisiete años, y fueseis candidatos al apaciguador calificativo de "jovencitos", yo siempre os llamaba, tácitamente, niños)..." (Swift, 1992, 14). Crick habla a sus alumnos como un padre lo haría con sus hijos. Nadie entiende lo que está haciendo, así que han decidido suprimir la asignatura: le exigen que su enseñanza «tenga relaciones prácticas y directas con el mundo actual» (Swift, 1992, 28). Mucho de lo que esta excelente novela nos suena a muchos profesores. La relación que ha establecido con su aventajado alumno Pierce, siendo como es paternal, al mismo tiempo manifiesta lucha y contradicción: el propio Crick es un signo de contradicción para su discípulo. Y por eso le dice: «Sólo los animales viven absolutamente metidos en el aquí y ahora. Sólo la naturaleza ignora la memoria y la historia. El hombre, en cambio [...] es el único animal que cuenta historias» (Swift, 1992, 61).

Todo hombre, toda mujer, llevan la marca de la influencia de algún maestro o maestra. Para la generación de Jacqueline de Romilly, una de las grandes filólogas griegas, la primera mujer en entrar en el Collège de France y miembro de la Académie Française, destaca por supuesto Alain, como para la generación de Deleuze, Jean-Paul Sartre. Pero Romilly cita a otros dos maestros: Paul Mazon y Jacques Desjardins. Ninguno de los dos buscaba tener discípulos ni poseerlos, pero causaban una inmensa admiración, y sonreían ante las adulaciones inmediatas y fáciles:

Cuando pienso en hombres como Mazon o como Desjardins, cuando pienso en lo que les debo, una gran ola de reconocimiento arrastra la amargura de la hora presente. Y a este reconocimiento se une el orgullo. Pues nuestra materia de enseñanza no está ligada a los parloteos, a los estatus, a las reivindicaciones, sean o no justificados: aparece en su pureza. Y entonces me siento presa del deseo de imitar a estos maestros, y dar todo lo que yo pueda dar, sea que los demás lo reclamen o no (Romilly, 1991, 48).

Mientras escribo estas líneas, me vienen a la memoria las clases, un poco caóticas, pero apasionantes al mismo tiempo, que impartía mi viejo profesor de historia 
de la educación, Federico Gómez Rodríguez de Castro, que se había formado en Alemania, y que, a menudo, nos decía que el estudio implicaba solo dos cosas: "libertad y soledad». Cuando pienso en él inmediatamente lo asocio a la benevolencia y a la calma; también al sentido del humor. Nos hablaba de sus años de aprendizaje allí, y también me veo a mí mismo escuchándole muy atento. Nos hablaba de historia de la educación (en realidad, de historia de las ideas educativas), y lo mismo nos citaba a Rousseau que a Goethe. Sobre todo, a los alemanes. Todo era, como digo, un poco desordenado. Llevaba con él libros que nos mostraba y de los que nos leía algunos párrafos. No sabría decir exactamente qué aprendí con él, pero sí lo que me pasó: me condujo, probablemente sin proponérselo, a la lectura y al estudio. La sensación que tengo ahora es que ese profesor tiraba flechas al azar y a mí me clavó una. Después de las clases, me quedaba pensando que yo también quería ser profesor de universidad, y entonces me encerraba en la biblioteca para leer los libros que él citaba en sus clases. Lo recuerdo con inmensa ternura. Y al hacerlo puedo asentir y decir: él fue mi maestro. Si estoy en la Universidad es por su causa.

El recuerdo de ese profesor que fumaba en pipa va unido al recuerdo del libro de Gusdorf, al que se añadiría, un poco después, mi primera lectura de Hannah Arendt: la edición francesa de Entre el pasado y el futuro, que llevaba por título La crise de la culture. También me llega a la memoria la primera vez que leí algo de Deleuze: fue su libro Proust y los signos. Lo leí rápido y fascinado. Muchísimas cosas se me escaparon de esa primera lectura, pero quedé entusiasmado. Ese ensayo me llevó a leer el primer volumen de En busca del tiempo perdido de Proust, y buena parte del último: El tiempo recobrado. Más adelante supe que Proust escribió el primer volumen y, a continuación, el último. Así que, sin saberlo, había procedido como el autor los había escrito. Muchos años después los leí todos, y me quedé asido entre sus páginas, completamente proyectado en las mismas inquietudes literarias del narrador, Marcel.

Todas estas referencias dan cuenta de algo esencial: lo inimaginable de «una sociedad donde la transmisión del saber no se realice sin la mediación del maestro, sin la relación física y fuertemente misteriosa que liga a quien enseña con quien aprende» (Stabile, 1988, 9). La relación maestro-discípulo, que como hemos dicho es una dimensión del mundo humano, es, más singularmente todavía, una dimensión crucial del mundo intelectual, y una dimensión bien real. En primer lugar, se trata de una relación elegida y, en segundo término, de una relación inscrita en un medio dado: en un espacio físico e institucional, ciertamente, pero también en un espacio anímico -espiritual, por así decir- que vincula la cadena de las generaciones en enigmáticos procesos de filiación y adopción (Waquet, 2008, 17). Dentro de este espacio anímico, como ha sugerido George Steiner, un maestro irrumpe, invade, y puede llegar a arrasar con el propósito de limpiar y reconstruir lo roto. De ahí, advierte que «una enseñanza deficiente, una rutina pedagógica, un estilo de instrucción que, conscientemente o no, sea cínico en sus metas meramente utilitarias, son destructoras. Arrancan de raíz la esperanza» (Steiner, 2003, 26). 
Conviene, sin embargo, no ser incautos en un asunto como el que estamos tratando. Pues la mutua elección entre maestros y discípulos es ajena a toda clase de seducciones y traiciones. De hecho, la enseñanza también es un ejercicio, declarado o implícito, de relaciones de poder: «El maestro posee poder psicológico, social, físico. Puede premiar y castigar, excluir y ascender. Su autoridad es institucional, carismática o ambas a la vez. Se ayuda de la promesa o la amenaza. El conocimiento y la praxis mismos, definidos y transmitidos por un sistema pedagógico, por unos instrumentos de educación, son formas de poder» (Steiner, 2003, 13-14).

\section{LA FILIACIÓN: UNA RELACIÓN ELEGIDA}

L'heure de cours est comme une oasis dans la trame des jours: c'est une heure réservée à la connaissance, à la vérite, à l'intelligence (Romilly, 1991, 33).

En 1942, estando recluido por sus actividades antifascistas en Florencia, el filósofo Guido Cologero escribió una carta de condolencia a Giovanni Gentile, que acababa de perder de forma brutal a su hijo, un físico de gran talento. Podemos dejar de lado ahora las actividades de Gentile al servicio del Duce, aunque es muy significativo que el "discípulo" contradijese precisamente en esto a su maestro. Cologero escribe: «Déjeme decirle, querido profesor, que habiendo sido encaminado por usted hacia mi vocación [...] de investigador y enseñante y considerándome un poco vuestro hijo espiritual (tal vez de manera inmodesta, y pese a la diferencia de ideas que mantenemos hoy en diversos dominios), me ha parecido, al recibir la noticia, que se me anunciaba la muerte de mi hermano, yo, que no tengo hermanos» (Farnetti, 1998, 203).

Esta carta pone de manifiesto que la relación entre maestros y discípulos es una relación filial. A menudo, los maestros que no tuvieron hijos adoptan, como a tales, a los discípulos que los han erigido en sus maestros. En esta relación filial, la función educadora se nutre de las funciones familiares del alimento (espiritual), el cuidado y la protección. El maestro las asume y las eleva al terreno de la guía, la orientación de la existencia, la disciplina. Los discípulos, agradecidos, recuerdan emocionados esas nobles funciones. Así, Charles Bouchard dice de su maestro Charcot: «Me ha conducido hasta el grado más elevado al que he podido acceder. Conservo por su memoria una piedad filial» (citado por Waquet, 2008, 172).

De la misma manera que los maestros pueden engañar a sus discípulos, estos, que a menudo se engañan a sí mismos, pueden confundir el sentido de la relación, hasta destruirla por entero. En la novela de Irish Murdoch El discípulo del filósofo, George MCaffrey anhela la llegada a Ennistone, tras una prolongada ausencia, de su maestro filósofo, John Robert Rozanov. La vida de Ennistone gira en torno al balneario, cuyo papel a menudo se compara con el ágora ateniense: un constante lugar de cita de la ciudadanía. Como Dante dice en la Divina Comedia, también George MCaffrey dice a su maestro: "Tu se' lo mio maestro e '1 mio autore». En el 
momento en que maestro y discípulo se encuentran, George, como hipnotizado y ridículo, declara:

Dios, qué real me siento ahora que por fin estoy contigo; mucho más real de lo que he sentido en años, en años. He anhelado tu presencia. John Robert, tienes que ayudarme. Tú robaste mi realidad, robaste mi consciencia, y eres la única persona que puede devolvérmela. La salvación es cosa de magia, lo dijiste una vez. Te suplico, te imploro. Se trata de mi salvación, es cuestión de vida o muerte (Murdoch, 1989, 165).

En su ensayo Lecciones de los maestros, Georges Steiner decía que hay tres estructuras de relación pedagógica principales. En primer lugar, un tipo de relación -bien ilustrada en la literatura-, en la que el maestro destruye a su discípulo en nombre de cierta concepción a priori de un ideal pedagógico y, en los casos más extremos, también psicológica o físicamente. La lista de obras que ilustran este caso es amplísima, como, por ejemplo, Las tribulaciones del estudiante Törless (1906), de Robert Musil, o Jakob von Guten (1909), de Robert Walser. En segundo lugar, está el caso de los discípulos que, al tergiversar el pensamiento de su maestro, acaban por destruirlo y, a su vez, traicionarlo. En el cine, cabe mencionar La soga, de Alfred Hitchcock (1948), y en el ámbito literario, El discípulo (1889), de Paul Bourget, o El discípulo del filósofo, de Irish Murdoch. Por fin, la tercera categoría es la de

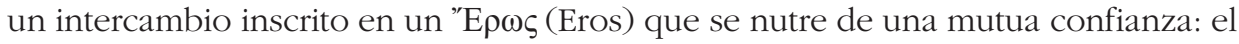
maestro aprende de sus discípulos tanto como estos de aquel; el bellísimo relato de Stefan Zweig Confusión de sentimientos da cuenta precisamente de este aspecto.

En los tres casos la cuestión de la autoridad y el poder se coloca en distinto lugar. En el primer caso, en el saber que el maestro supuestamente encarna; en el segundo, en la identidad y la diferencia que el discípulo manifiesta; en el tercero, en la disciplina estudiosa que el maestro promueve en el otro a través de la materia colocada en medio de la relación. La cuestión de la autoridad atraviesa, por otro lado, los tres escenarios. Hannah Arendt ya dijo que tenemos un problema con la palabra autoridad, precisamente en un mundo no articulado en torno a ese concepto: "La autoridad se ha esfumado del mundo moderno", señaló (Arendt, 1996, 101). Como ya no podemos apoyarnos en experiencias auténtica e indiscutiblemente comunes a todos, la propia palabra «autoridad» está ensombrecida por la confusión y la controversia. Para la pensadora alemana, esta crisis presenta una naturaleza política, a causa de los movimientos totalitarios que invadieron el siglo xx, y el síntoma más significativo de dicha crisis de la autoridad es su expansión hacia áreas que son por naturaleza prepolíticas, como la educación de los niños, donde la autoridad siempre se aceptó como algo natural. Así que, sugiere Arendt, "tanto en la práctica como en la teoría, ya no estamos en condiciones de saber qué es verdaderamente la autoridad» (Arendt, 1996, 102). Su tesis, en fin, es que la autoridad no es una matriz del espacio, sino una categoría del tiempo. Si se pierde la autoridad, decía Arendt, se pierde el fundamento del mundo; pero la falta de seguridad que conlleva no implica, necesariamente, la pérdida de la capacidad 
humana para construir y preservar un mundo común que continúe siendo un lugar adecuado para las generaciones nuevas.

Para quienes el asunto de la autoridad se resuelve apelando a una mayor "disciplina» en las aulas, bastará con recordarles que la "disciplina» del aula casi siempre tiene que ver con la autoridad que se concentra en el objeto que se estudia y se coloca en medio de una relación. Si se logra que toda la atención esté en ese objeto, en la "cosa" que se coloca ahí -como también sugiere Rancière (2002)-, entonces no hay lugar ya, salvo en casos extremos y muy particulares, para invocar otra clase de orden o poder disciplinario. Uno puede, como padre o como profesor, pretender garantizarse la paz en el hogar, o en su caso en el aula, a base de medidas sobreprotectoras, o mediante una especie de contrato de mutua no exigencia, del tipo: "Vamos a ver, dejémoslo claro: tú no me incordias, yo no te exijo». También podemos dejar de prestar atención al pronombre tras el cual, con frecuencia, algunos alumnos se esconden cuando dicen: "Nunca lo conseguiré, señor». Veamos cada uno de estos casos con dos ejemplos.

Sobre lo primero, el cineasta, poeta, filósofo, educador -o, como a él mismo le gustaba llamarse, "etólogo»- Fernand Deligny (1913-1996) decía algunas cosas de interés en un texto publicado en 1945, que es un conjunto de aforismos titulado Graine de crapule, y que iba dirigido a jóvenes educadores en formación. Deligny escribe este texto en una época en la que trabaja con jóvenes profundamente inadaptados, y constituye un ataque al paternalismo, al psicologismo y al activismo jurídico de la Sauvegarde de l'enfance ("Salvaguarda de la infancia»). Su posición se resume en la frase: "Lo que queremos nosotros es ayudarlos, no amarlos». Estos aforismos surgen directamente de la violencia de la guerra, de la miseria de las ciudades y del proletariado, de donde proceden mayoritariamente los menores delincuentes de la posguerra. Uno de ellos dice así:

Tienes que saber lo que quieres. Si es hacerte querer por ellos, llévales caramelos. Pero el día que te presentes con las manos vacías, dirán que eres un cerdo. Si quieres hacer tu trabajo, tráeles una cuerda de la que tirar, leña que partir, sacos que cargar. El amor vendrá luego, y ésta no es tu recompensa (Deligny, 1996, 20).

Por lo que respecta a las máscaras tras las cuales muchos alumnos se ocultan, el novelista Daniel Pennac, en Mal de escuela, observa lo siguiente:

Nuestros "malos alumnos" (de los que se dice que no tienen porvenir) nunca van solos a la escuela. Lo que entra en clase es una cebolla: unas capas de pesadumbre, de miedo, de inquietud, de rencor, de cólera, de deseos insatisfechos, de furiosas renuncias acumuladas sobre un fondo de vergonzoso pasado, de presente amenazador, de futuro condenado. Miradlos, aquí llegan, con el cuerpo a medio hacer y su familia a cuestas en la mochila. En realidad, la clase solo puede empezar cuando dejan el fardo en el suelo y la cebolla ha sido pelada. Es difícil de explicar, pero a menudo solo basta una mirada, una palabra amable, una frase de adulto confiado, claro y estable, para disolver esos pesares, aliviar esos espíritus, instalarlos en un presente rigurosamente indicativo [...] Habría que inventar un tiempo especial para 
el aprendizaje. El presente de encarnación, por ejemplo. ¡Estoy aquí, en esta clase, y comprendo por fin! ¡Ya está! Mi cerebro se difunde por mi cuerpo: se encarna. Cuando no es así, cuando no comprendo nada, me deshago allí mismo, me desintegro en ese tiempo que no pasa, acabo hecho polvo y el menor soplo me disemina. Pero para que el conocimiento tenga alguna posibilidad de encarnarse en el presente de un curso, es necesario dejar de blandir el pasado como una vergüenza y el porvenir como un castigo (Pennac, 2008, 60-61).

Ni Deligny ni Pennac dicen que estar en medio de una relación profesoralumno sea algo fácil. De hecho, es una de las cosas más difíciles de gestionar. Pero ambos sugieren que lo que hay que hacer es estar ahí, presentes, con esos chicos y chicas, haciendo lo posible, aunque no a cualquier precio, por ayudarles. Deligny dice: «Si quieres hacer tu trabajo, tráeles una cuerda de la que tirar, leña que partir, sacos que cargar»; y Pennac sugiere en algún momento que los problemas con la gramática (o con las matemáticas o con la filosofía, etc.) se resuelven con "gramática", con "matemáticas", con "filosofía». Como observan Simons y Masschelein en Defensa de la escuela, una manera de ayudarles podría consistir en hacer de la escuela -y del aula- un espacio y un tiempo libres que suspendan tanto el lastre del pasado de los alumnos como la presión potencial del futuro ya proyectado, o perdido (Simons y Masschelein, 2014, 37); es decir, y dicho ahora en términos arendtianos, cuando logramos colocar el acto educativo entre pasado y futuro (Arendt, 1996), es decir, en ese presente de indicativo del que habla Pennac en su novela.

La pérdida de ese fundamento del mundo que examina Arendt explica, para algunos, el malestar contemporáneo de la juventud, el cual tiene que ver con un "eclipse de la autoridad simbólica", como dice Massimo Recalcati: "La autoridad simbólica del padre ha perdido peso, se ha eclipsado, ha llegado irremisiblemente a su ocaso» (Recalcati, 2014, 11). Según este psicoanalista, este reclamo del padre no tiene que ver con la imagen del pater familias -figura afortunadamente abandonada y caduca- que ostentaba la patria potestas y que ejercería su derecho de «hacer morir o dejar vivir", como señaló Foucault (Foucault, 2002, 167), sino con la pregunta acerca de lo que queda del padre en la época de su propia disolución. Recalcati ofrece como imagen de referencia a Telémaco, que encarna la figura del hijo que espera la llegada del padre desconocido (Ulises), a quien busca como la posibilidad de que la ley de la palabra (y de la cultura) se instaure de nuevo en un mundo derrotado (donde las generaciones parecen confundirse). En su ensayo, Recalcati insiste en que hoy no nos hacen falta ni retóricas pedagógicas, ni peroratas moralistas o sermones edificantes (Recalcati, 2014, 155), aunque el tono de su propio ensayo es bastante enfático y no muy alejado, en ocasiones, de algún tipo de sermón.

No obstante, sí es cierto que el oficio educador (sea el de los padres en el hogar, o el de los profesores en las aulas) es cada vez más complejo, y también que ni unos ni otros (padres y profesores) tienen por qué encarnar un ideal normativo de vida moral, pues la educación siempre se ejerce desde el horizonte del riesgo y el fracaso potencial. Hay cierta imposibilidad en el arte de educar. Ilustraré esta imposibilidad con dos textos: 
Mi figura de pedagogo se halla pues irremisiblemente en crisis. No se puede enseñar si no se aprender alguna cosa. Y ahora yo no puedo enseñarte las 'cosas' que me han enseñado a mí, ni puedes enseñarme tú las 'cosas' que te están educando a ti (o sea, las que estás viviendo). No nos las podemos enseñar mutuamente por la sencilla razón de que su naturaleza no se ha limitado a mudar alguna de sus cualidades, sino que ha cambiado radicalmente en su totalidad [...] La verdad que hemos de decirnos es la siguiente: la nueva producción de las cosas, o sea el cambio de las cosas, te da a ti una enseñanza originaria y profunda que yo no puedo comprender (entre otras cosas porque no quiero). Y eso explica una extrañeza entre nosotros dos que no es meramente la que durante siglos y milenios ha separado a los padres de los hijos (Pasolini, 2010, 43-45).

El segundo texto es un fragmento de la novela de John Steinbeck Al este del Edén, en la que un padre (Cyrus) le dice a su hijo Adam, que está dispuesto a ir a la guerra, algunas cosas que cree haber aprendido en relación con el modo como los seres humanos se comportan en la guerra:

He estudiado cómo son las cosas, y quizá he aprendido algo, pero estoy todavía lejos de saber por qué son como son. Y no debes esperar que los hombres comprendan la razón de sus acciones. Muchas cosas se hacen de modo instintivo, de la misma manera que una abeja hace miel o una zorra hunde sus patas en el curso de un riachuelo para engañar a los perros. La zorra es incapaz de decir por qué actúa así, y la abeja, probablemente, no recuerda el invierno ni espera que éste vuelva. Cuando supe que tendrías que abandonarme, pensé que no debía entrometerme en tu futuro para que así fueras capaz de hallar tu propio camino, pero después me pareció mejor ayudarte con lo poco que yo sé. Pronto te irás, ya tienes edad (Steinbeck, 2009, 37).

Ni el pedagogo imaginario de Pasolini (que se dirige a un muchacho napolitano de unos quince años) ni el padre de Adam parecen tener muy clara su labor. Más bien manifiestan sus dudas. Cyrus le dice a su hijo: "Pronto te irás, ya tienes edad», y esta afirmación entraña una profunda verdad, si es cierto que el acto educativo acarrea consigo el destino de la separación que acompaña la relación educativa (la de los padres con sus hijos, la de los maestros con sus discípulos). Porque no hay educación que no implique una salida al exterior, una separación, cierta clase de ruptura. Pasolini, por su parte, le hace decir a su pedagogo que "ya no nos podemos enseñar (las cosas) mutuamente» porque han cambiado radicalmente en su totalidad, o sea, porque ya no tenemos un fundamento común para el mundo. Y por eso hay una profunda extrañeza entre padres e hijos, entre profesores y alumnos. Y es en estas condiciones de extrañeza y de imposibilidad donde hay que inscribir un pensamiento sobre la relación educativa. A menudo, los hijos han de tomar sus propias decisiones sin el apoyo de una tradición, de una autoridad simbólica o no, de una paternidad, entendida en sentido amplio, que les sostenga. Hay una especie de sentimiento de abandono.

En su diario Au dos de nos images, 1991-2005, el cineasta belga Luc Dardenne, en una entrada del 23/12/1999, sugiere una interesante reflexión cuando señala 
que hoy los padres ya no prohíben nada a sus hijos: «En nombre de qué o de quién lo harían?», se pregunta: "Dejan al niño ser por sí mismo, para sí mismo, en sí mismo, consigo mismo. Es un modo de comérselo para que él no se los coma a ellos. Ése es su miedo, su terror: ser comidos por aquellos a los que trajeron al mundo, por aquellos que vienen de ellos. Entonces no les dicen de dónde vienen, les hacen creer que no vienen de otro, sino que vienen de sí mismos y que sólo puede echarse la culpa a ellos mismos. ¿Que esos niños se coman entre ellos!» (Dardenne, 2005, 103).

Nadie proviene ni nace de sí mismo, aunque todos, quizá, estamos destinados a un gesto que nos haga nacer de nosotros mismos (por ello tal vez la educación puede interpretarse como un acto de nacimiento o natalidad). De ahí que sea tan expresiva la imagen que se nos ofrece en un momento de la novela Frankenstein o el moderno Prometeo, una vez que la criatura ha sido creada y después abandonada por su horrorizado creador: «iMaldito creador! ¿Por qué me hiciste vivir? ¿Por qué no perdí en aquel momento la llama de la existencia que tan imprudentemente encendiste? [...] Maldito sea el día en que recibí la vida, maldito sea mi creador» (Shelley, 2006, 177). Arendt termina su ensayo sobre la crisis de la educación diciendo que

[La educación] es el punto en el cual decidimos si amamos al mundo lo suficiente como para asumir una responsabilidad por él, y de esa manera salvarlo de la ruina inevitable que sobrevendría si no apareciera lo nuevo, lo joven. Y la educación también es donde decidimos si amamos a nuestros niños lo suficiente como para no expulsarlos de nuestro mundo y dejarlos librados a sus propios recursos, ni robarles de las manos la posibilidad de llevar a cabo algo nuevo, algo que nosotros no previmos; si los amamos lo suficiente para prepararlos por adelantado para la tarea de renovar un mundo común (Arendt, 1996).

El «amor» del que habla Arendt no es un recurso al sentimentalismo fácil, sino que se trata del amor al mundo (Amor Mundi), porque la tarea de la escuela no es instruir en el arte de vivir, sino la transmisión del mundo. Y sobre esto no hay ni especialistas, ni expertos ni profesionales. Tampoco programas que nos faciliten el camino. Es un acontecimiento y está instalado en la contingencia.

Planteadas las cosas en estos términos, la cuestión de la autoridad, en educación, no tiene ya que ver con un orden disciplinar, ni con una normatividad moral instaurada en una nueva figura del pater familias. Tiene que ver con lo que pasa cuando experiencias del tiempo del todo diferentes -el tiempo joven de los recién llegados y el tiempo de los adultos- se dan cita en un presente comunicándose algo de lo que saben sin poder compartirlo todo, como observaba Pasolini en la cita anterior. Es cierto que tampoco en educación vivimos en el mejor de los mundos, pero incluso bajo tales condiciones es posible -aunque sea difícil, incluso dificilísimo- hacer algo. Al menos es posible tratar de caer en la cuenta, y hacer que quienes aprenden tomen conciencia de las cosas que de verdad importan. Esto nos los recuerda alguien como Fritz Zorn en sus memorias Bajo el signo de Marte, un joven que con apenas 32 años muere de cáncer habiendo vivido casi toda su 
vida como un neurótico encerrado en una familia burguesa para la cual lo que verdaderamente importaba siempre debía dejarse para más tarde:

Las pequeñas o grandes debilidades de mis padres no eran malas en sí mismas: nadie es perfecto y ninguna educación puede dar resultados perfectos, puesto que en algún momento durante el transcurso de la educación todos los padres impondrán indudablemente a sus hijos algo que más adelante los hará sufrir. Además, los niños no son criaturas perfectas, y esto forma parte de algo evidente: simplemente, el mundo no es perfecto. Lo malo no eran mis padres, ya que ellos no eran malvados; hoy sólo puedo sentir piedad por ellos. Lo que era malo era el hecho de que el mundo en el cual yo crecía no debía ser un mundo imperfecto, ya que su armonía y su perfección eran obligatorias. Yo no debía caer en la cuenta de que el mundo no era perfecto; la principal finalidad de mi educación podría encontrarse seguramente en el hecho de que ella trataba justamente de hacer imposible el momento en el que yo me diría: «iAlto!», ya que me habían educado de manera que no pudiera caer en la cuenta. Y tuvo éxito. Mi educación puede calificarse en realidad de perfectamente lograda, ya que, durante treinta años, yo no "caí en la cuenta» de nada. Fui educado para decir siempre sí, «utilicé lo que había aprendido", y siempre dije sí a todo. La experiencia de mi educación había tenido éxito. Lamentablemente (Zorn, 2009, 68-69).

Aunque la presencia en el seno de una relación pedagógica (a la vez, relación de aprendizaje, y quizá relación educativa) es algo importante -es decir, estar plenamente en lo que enseñamos, en lo que aprendemos, en lo que pensamos y en lo que nos pasa allí, como profesores y como alumnos-, seguramente el objetivo último es desaparecer. Una de las peores patologías pedagógicas es pretender prolongar la situación de dependencia, y también invitar, seductora y manipuladoramente, a que nuestros alumnos transiten caminos que nosotros nunca recorreríamos y para los cuales ellos no están preparados. Al final de su novela, Pennac viene a decir que los profesores que le salvaron, y que hicieron de él el profesor que llegó a ser, no estaban preparados para esa tarea; tampoco perdieron el tiempo explorando el origen de su propia incapacidad como alumno "zoquete», ni sus causas, ni se pasaron la vida sermoneándole. Simplemente eran adultos enfrentados a un adolescente completamente perdido. Y por eso se tiraron a la piscina, le cogieron y le subieron a la superficie. Insistieron una y otra vez hasta lograr ayudarle. Podría no haber sido así. Podrían haber fracasado, pero el caso es que insistieron una y otra vez hasta lograrlo. Cada uno de sus profesores encarnaba aquello que estaban enseñando: la profesora de historia, la historia; el profesor de filosofía, la filosofía; el de matemáticas, las matemáticas. Y lo hicieron con pasión. Porque amaban lo que hacían. Porque se habían enamorado de lo que transmitían, y supieron transmitir ese amor, esa pasión.

\section{SEDUCCIONES Y TRAICIONES PEDAGÓGICAS}

Nunca he vuelto a verlo. Nunca he recibido una carta o un mensaje de él. Su libro no ha sido publicado, su nombre ha caído en el olvido; nadie lo recuerda salvo yo. 
Pero todavía hoy, como el muchacho inseguro de entonces, sé que a nadie debo más: ni a mi padre, ni mi madre antes que él, ni a mi esposa e hijos después de él. A nadie he amado tanto (Zweig, 2013, 105).

La relación maestro-discípulo es, como hemos visto, una relación elegida, y en ella la atracción -incluso erótica- entre los miembros de la relación resulta inevitable. Es un asunto que no se puede obviar. Los versos de Hörderlin -«Sócrates y Alcibíades»- son bien significativos al respecto:

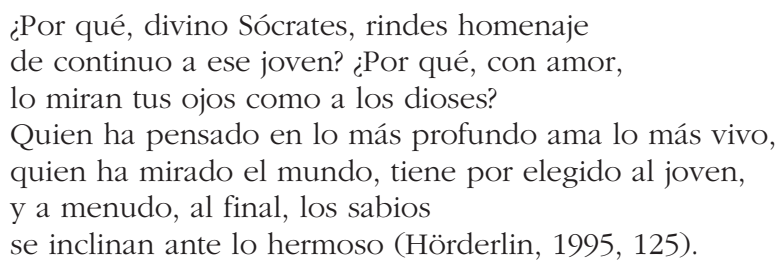

Antes escuchamos algunas evocaciones de maestros por parte de sus discípulos agradecidos. El discípulo que agradece, lo que en realidad está reconociendo es su propio nacimiento segundo. Pues el verdadero maestro es quien engendra una posterioridad, donde nuevos maestros -sus propios discípulos- lograrán serlo. El maestro engendra el tiempo, y él mismo es posible por causa del tiempo mismo. Es un padre, el maestro, según el espíritu: un padre que engendra espíritus siendo sus discípulos hijos espirituales. Una corriente de afectos, pasiones y amores atraviesa la relación. El maestro, como le ocurre al pretencioso Alcibíades, es el único digno de erigirse en el amado del amante-discípulo: "Creo que tú eres el único digno de convertirse en mi amante", dice Alcibíades al final del Banquete de Platón (218c). Y a eso Sócrates responde: "Mi feliz amigo, examínalo mejor, no sea que te pase desapercibido que no soy nada. La vista del entendimiento, ten por cierto, empieza a ver agudamente cuando la de los ojos comienza a perder su fuerza, y tú todavía estás lejos de eso» (219a). Por supuesto, el arrogante discípulo se sentirá aquí humillado y vencido -aunque no deje de reconocer la superioridad de aquel a quien ama: Sócrates-. Pero quizá ya se ha introducido algo en la indisciplinada y desatenta alma de Alcibíades. Steiner lo dice con claridad en su libro sobre los maestros: "El erotismo, encubierto o declarado, imaginado o llevado a la práctica, está entretejido con la enseñanza, con la fenomenología del Magisterio y el discipulazgo. Este hecho elemental ha sido trivializado por una fijación en el acoso sexual. Pero sigue siendo esencial. ¿Cómo podría ser de otro modo?» (Steiner, 2003, 33). Pocas veces reparamos en estas cosas, tanto en las maravillas de la transmisión como en el misterio que le es inherente.

Si educere simboliza la conducción hacia la luz (tender la mano, guiar, conducir, empujar, llevar afuera), seducere significa, en romano antiguo, separar del domus, llevar al otro (a la mujer o al amado o amada) a la casa propia (la del amante), separarlo de la casa familiar. Es llevar a un lugar apartado, secreto (secretus), fuera de las miradas de los otros (los amantes se apartan, se esconden). El reino de los amantes que se seducen es un reino que no es de este mundo. De 
ahí que el amante quiera exclusividad y tenga la tentación de secuestrar al amado o la amada, como hace el narrador de En busca del tiempo perdido, Marcel, con Albertine, su amada. En el «educere» y en el «seducere» está, no obstante, el duce, el guía que puede devenir un déspota o un tirano. El que no suelta de la mano al pueblo, al que infantiliza en vez de emanciparle; el que aprieta con la garra. Hay que tratar de entenderse sobre esta cuestión. ¿Qué significa la seducción en la relación maestro-discípulo? ¿Cómo interpretarla?

Retrocedamos en el tiempo. En las clases aristocráticas de la Grecia clásica existía toda una ritualización de la entrega del joven imberbe (eromenós) al adulto (erastés) con el que iba a convivir separadamente de la familia y que le iniciaría en la virtud y la sabiduría. Es el rapto del discípulo, que en esa entrega al mismo tiempo celebra la diferencia de las edades y las generaciones, concediendo importancia a la edad adulta (Marrou, 2004, 46-57; Boissinot y Ferry, 2017, 32-35). Es esta tradición la que Platón parece recoger en la República, cuando defiende la pederastia como pedagogía: ella misma consiste en un amor educador mediante el cual el erastés forma al eromenós en la virtud y el saber, pues de la belleza de los cuerpos hay que pasar a las bellas almas. La problemática que aquí se plantea es muy diferente a la de la homosexualidad, aunque es cierto que la antigua sociedad griega consideró como la forma más característica y noble del amor la relación personal entre varones de distinta edad. Esa relación evoca cierto compañerismo guerrero, por lo que, en todo caso, puede decirse que la "homosexualidad griega es de tipo militar» (la pareja de soldados que se cuidan mutuamente y se convierten en amantes) (Marrou, 2004, 48).

Esa diferencia de edad es importante, como decimos, y puede llegar a ser la cumbre del buen y el mal uso de la relación. Pues es lógico que el primero desee afirmarse tratando de seducir al segundo, hasta engendrar en él un sentimiento de admiración. En ese sentido, el adulto siente nacer en él, cuenta Marrou, una vocación pedagógica que lo instituye en maestro de su amado discípulo. Se abre la puerta para una influencia pedagógica que, en algunos casos, no se corrige a sí misma en sus propósitos.

En la novela de Oscar Wilde El retrato de Dorian Gray, el mentor del joven Dorian, Lord Harry, considera su relación con el joven como un experimento pedagógico cuyo principio básico es que «el fin de la vida humana es el desarrollo personal. El perpetuo desarrollo de la propia naturaleza: he ahí nuestra razón de ser. Hoy en día la gente tiene miedo de sí misma. Han olvidado su principal deber, el deber que un tiene consigo mismo» (Wilde, 1989, 61). En función de ese principio, Lord Harry considera que hay algo terriblemente seductor en el ejercicio de la influencia (además, la belleza y la juventud de Dorian son indiscutibles). Ahora bien -le advierte a Dorian- "la buena influencia no existe, señor Gray. Toda influencia es inmoral -inmoral desde el punto de vista científico» (Wilde, 1989, 61). Influir en una persona es entregarle el alma.

En su moralista novela El discípulo (1889), Paul Bourget narra, a partir al parecer de algún hecho real acontecido en su época, la historia y consecuencias de una 
relación entre un maestro (Adrien Sixte) y su discípulo (Robert Greslou) condenado a muerte por el supuesto asesinato de una alumna de la que era su preceptor. Greslou dice haber seguido las teorías del maestro, que le han influido notablemente. Escribe una memoria relatando los hechos que el maestro, alucinado, leerá:

Existe entre usted, el maestro ilustre, y yo, su alumno, acusado del crimen más infame, un vínculo que los hombres no sabrían comprender, que usted mismo ignora, y que yo siento tan estrecho como irrompible. ¡He vivido con su pensamiento, de su pensamiento, tan apasionadamente, tan enteramente durante la época más decisiva de mi existencia! Ahora y en el desamparo de mi agonía intelectual, me dirijo a usted como al único ser del que pueda esperar, implorar, una ayuda (Bourget, 2010, 121).

Sin proponérselo quizá, el maestro ha seducido e influido en su discípulo. Leyendo el manuscrito, Sixte dirá: «Un maestro está unido al alma que ha dirigido, aunque no haya querido esa dirección, aunque esa alma no haya interpretado bien la enseñanza, por una especie de lazo místico, y que no permite oponer a ciertas agonías morales el gesto indiferente de Poncio Pilatos» (Bourget, 2010, 303-304). Sixte se siente aterrado por las palabras de Greslou. Todos sus esfuerzos intelectuales parecen haber traído como consecuencia un "principio de muerte»:

A medida que Sixte avanzaba en el manuscrito, le parecía que un poco de su ser íntimo se ensuciaba, se corrompía, se gangrenaba, tanto encontraba de sí mismo en ese joven, pero un «sí mismo» íntimamente ligado, ¿por qué misterio?, a los sentimientos qué más odiaba en el mundo. Esa siniestra historia de una seducción tan bajamente conducida, de una traición tan negra, de un suicidio tan melancólico, le ponía cara a cara con la más espantosa visión: la de su pensamiento actuante y corruptor, él que había vivido en la renuncia y con un ideal cotidiano de pureza. Toda la aventura de Robert Greslou le mostraba sus libros como los cómplices de un odioso orgullo y de una abyecta sensualidad, él que nunca había trabajado más que para servir a la psicología, como modesto obrero de un trabajo que creía bienhechor, e imponiéndose el ascetismo más severo, a fin de que los enemigos de sus doctrinas nunca pudieran argüir su ejemplo contra sus principios (Bourget, 2010, 296).

El tema de El discípulo se presenta como un motivo moral y, más allá del evidente moralismo de Bourget, que tanto enojaba a André Gide, la novela es un buen pretexto para tratar el asunto de la influencia que los maestros ejercen sobre sus discípulos, sea directamente o a través de sus obras. Dicho con Steiner: «iHay un derecho a la inmunidad magisterial, a la manera de Poncio Pilato?» (Steiner, 2003, 99). Lo que Bourget plantearía es una reflexión sobre la influencia pedagógica (y sus límites), pero lo que la novela propone, además, es un análisis de una forma esencial de traición pedagógica por parte de un discípulo que anhela seguir siéndolo eternamente y que no ha entendido lo que Nietzsche proclamó: "Se paga mal a un maestro si se permanece siempre discípulo» (Nietzsche, 1998, 12).

Mucho más de lo que irradie de la figura del maestro o del discípulo, importa la luz que emana de lo que se coloca en medio de la relación: no el aprender, sino 
el saber y su deseo. Pues todo gira en torno a ese deseo de saber. Y toda la erotización se coloca ahí. Sócrates advierte a Alcibíades que quizá se equivoca, que no hay nada en él -en el propio Sócrates- que, puesto que es un filósofo, nada sabe, pues lo busca incesantemente. Y el saber no se traslada como de una vasija llena a otra vacía. No es así de fácil. El discípulo debe hacer algo: aprender junto al maestro, no como él. El maestro habla, y coloca en medio de la relación su palabra, su cuerpo y toda su pasión. Es probable que el discípulo quede atrapado en esa red que ha tejido, como seducido. Lo difícil es tratar una y otra vez de que el discípulo no se desvíe del camino. El maestro está ahí para que el discípulo no salga del asunto, para que se esfume, y para que libremente se desplace en el interior del texto que están leyendo juntos. En El profesor del deseo, David Kepesh -un bribón entre los sabios, un sabio entre los bribones- sublima los poderes de seducción de los que hace gala en la mejor literatura que da a leer a sus alumnos:

Me encanta enseñar literatura. Pocas veces me siento tan feliz y contento como
cuando estoy aquí con mis páginas de anotaciones y mis textos llenos de marcas
y con personas como ustedes. En mi opinión, no hay en la vida nada que pueda
compararse a un aula. A veces, en mitad de un intercambio verbal -digamos, por
ejemplo, cuando alguno de ustedes acaba de penetrar, con una sola frase, en lo
más profundo de un libro-, me viene el impulso de exclamar: «Queridos amigos,
graben esto a fuego en sus memorias!.. Porque una vez que salgan de aquí, raro
será que alguien les hable o los escuche del modo en que ahora y se hablan y se
escuchan entre ustedes, incluyéndome a mí, en esta pequeña habitación luminosa
y yerma (Roth, 2012, 181).

El profesor les está diciendo que eso que ocurre en el aula es algo único que jamás se volverá a repetir. Y parece que sus palabras esconden otras cosas. Desde el momento en que una simple referencia a una obra mueve a uno de sus estudiantes a salir corriendo a la biblioteca para llenar la mochila de los libros citados allí, la sensación es, casi de forma inmediata, la de estar a punto de ponerse a conversar con los muertos que, en ese acto de lectura, cuando los libros comiencen a ser leídos, volverán a cobrar vida propia. Es algo único. No tiene precio. No se puede evaluar, ni medir, ni calcular. El maestro no se limita a enseñar una materia o unos contenidos. Enseña un amor: su amor por la materia que al mismo tiempo que enseña encarna. Enseña la historia de amor que tiene con lo que enseña: las horas de lectura y estudio, las notas de los cuadernos, los viajes y las andanzas. ¿Cómo incluir esto en alguna clase de "evaluación docente», como ahora se la denomina?

Cuando daba clases, se encontraba de vez en cuando tan abstraído en su asignatura que se olvidaba de su insuficiencia, de sí mismo, e incluso de los alumnos que tenía enfrente. De vez en cuando se sentía tan arrebatado de entusiasmo que tartamudeaba, gesticulaba e ignoraba los apuntes de clase que normalmente guiaban sus discursos. Al principio le molestaban esos arranques, como si se tomara demasiadas confianzas con su asignatura, y se disculpaba con sus alumnos, pero cuando 
empezaron a reclamarle después de las clases, y cuando sus ejercicios empezaron a mostrar indicios de imaginación y la revelación de un amor vacilante, se animaba a hacer aquello a lo que nunca le habían enseñado. El amor a la literatura, al lenguaje, al misterio de la mente y el corazón manifestándose en la nimia, extraña e inesperada combinación de letras y palabras, en la tinta más negra y fría -el amor que había ocultado, como si fuera ilícito y peligroso, empezó a exhibirlo, vacilante en un principio, luego con temeridad y después con orgullo [...] Sospechaba que comenzaba, con diez años de retraso, a descubrir lo que era y lo que veía era, más o menos lo que había imaginado que sería. Sentía por fin que empezaba a ser profesor, lo cual era simplemente ser un hombre a quien el libro le dice la verdad, a quien se le concede una dignidad artística que poco tiene que ver con su estupidez, debilidad o insuficiencia como persona. Era un conocimiento que no podía expresar pero que le había cambiado y gracias al cual su personalidad se volvió inconfundible (Williams, 2015, 102-103).

Como el amado (o la amada) para el amante, el maestro es una creación del discípulo, una creación amorosa, por tanto, subjetiva y contradictoria, que se rige por las leyes del amor y de la estética. Ahora bien, la estética exige una subjetividad profunda que se sitúa más allá del alcance de la ideología, como dice Harold Bloom $(2001,20)$ siguiendo a Kant.

El asunto que estamos tratando, pues, no pasa exclusivamente por el aprendizaje: «El deseo del profesor es algo más. Es un deseo excéntrico al deseo de guiar las vidas o las conciencias. No es deseo de educar, ni deseo de hacer aprender. Es, si acaso, deseo por el saber, es deseo de enseñar sin que haya un propósito deliberado de formar» (Recalcati, 2016, 113). El asunto tiene que ver con algo que nos llama, que nos seduce, que nos empuja, que nos atrapa. Tiene que ver con una vocación que nos impone un régimen de existencia, toda una dietética (como aquella de la que hablaban los antiguos griegos) y una economía de los gustos. Es otra cosa y no sabemos muy bien cómo explicarla, porque da casi miedo pronunciar la palabra esencial. Tiene que ver, sí, con esa vocación, y con una especie de amor; un amor antiguo, ancestral, en cuya historia nos hemos inscrito y que nos envuelve cuando decidimos dar el salto al torrente de la historia y del pasado. Es algo muy parecido a una historia que el hijo primogénito de Thomas Mann -Klaus Mann- escribe en su hermosa novela El volcán.

La joven Marion sale al escenario de un pequeño teatro parisino. Refugiados de la Alemania nazi viven en París y un grupo de amigos han ido a escuchar a Marion recitar poemas antiguos. Marion comienza recitando la oda "A la alegría», de Schiller. De pie, inmóvil, reprime sus gestos, y recita y recita: «El brillo de su mirada en tan excesivo esfuerzo resultaba tan aterrador como fascinante» (Mann, 2003, 218). Los versos fluyen, y la voz de Marion logra extraer las notas más hermosas y sorprendentes: seduce, gruñe, gime, canta, llora, y los asistentes se preguntan cómo es posible que en una sola persona se reúnan tantas y tan distintas facetas y que conmueva hasta tal punto. En cada uno de los versos escogidos por Marion hay una referencia al presente, pero «nunca resultó dogmática; clara siempre» (Mann, 2003, 218). Y de repente... de repente, todos entienden: "Los de la sala 
comprendieron: ni nuestras penas ni nuestras ideas son tan modernas y nuevas como solemos creer en nuestro entusiasmo primero. Otros ya las han sufrido y pensado antes, y han tenido que enfrentarse a los mismos problemas que nosotros. Sin embargo, sus ideas han dejado el gran legado de su sabiduría y su dolor convertido en arte» (Mann, 2003, 219).

La corrección que la orientación hacia el saber produce en la seducción pedagógica, para que no se desvíe de su cauce, impone como criterio la responsabilidad como centro de la relación entre maestros y discípulos. Así lo expresaba hace tiempo Claudio Magris:

Responsabilidad significa pagar el precio que comportan cada afirmación y cada acción, afrontar las consecuencias de cada toma de posición y las renuncias implícitas en toda elección; significa en primer lugar [...] no empujar a los demás hacia caminos que éstos (los alumnos) no son capaces de recorrer [...] Maestro es quien no ha programado serlo. Quien, por el contrario, se las da de pequeño Sócrates es fácilmente patético (Magris, 2001, 41-42).

Esta responsabilidad de la que habla Magris no renuncia a la mediación del maestro en la existencia del otro; más bien la matiza y la corrige. Como decía Foucault, la gran lección de la ética griega es que «uno no puede ocuparse de sí mismo sin la mediación del maestro, no hay inquietud de sí sin la presencia de un maestro" (Foucault, 2001, 58). Ahora bien, lo que define su posición es el cuidado que el maestro ha de poner en la preocupación que el discípulo tenga sobre sí mismo, sobre su propio cuidado de sí: «El maestro es quien se preocupa por la inquietud que el sujeto tiene con respecto a sí mismo y quien encuentra, en el amor que siente por su discípulo, la posibilidad de preocuparse por la preocupación de éste en relación consigo mismo" (Foucault, 2001, 58).

La confianza, el crédito hacia el maestro mantiene la condición del discípulo en su discipulazgo. Pero no hay más que observar caso a caso para darse cuenta de las patologías que acaecen en el magisterio. Pues hay una condición del discípulo que un falso maestro provoca, que instituye una especie de fe teológica en el otro, al que sacraliza. Entonces el maestro es aquel de quien se recibe toda la seguridad en relación con una verdad que deviene dogmática. Entonces, el maestro vive por procuración, custodiado por aquel a quien se ha erigido en maestro salvador. Quien recita la lección del maestro, le traiciona. Hay aquí, como ya observó Gusdorf, una admiración descarriada de costosas consecuencias. Si es una gran suerte haber encontrado un maestro, es en verdad una desgracia permanecer siempre discípulo, atrapado de la enseñanza recibida, bloqueado en su desarrollo. Pensar como el maestro no es todavía pensar. La tentación de la seducción, cuando esta se pone en la figura y no en el asunto que concita la relación, consiste entonces en que el maestro se enseñe a sí mismo, lo que es una forma de defraudar la verdad que ambos han de buscar. De ahí que, junto a la amistad espiritual, al proceso de filiación y adopción mutua entre maestro y discípulo, el momento de la ruptura y del adiós -pues hay que aprender a despedirse- sea el mejor modo de celebrar una relación que unió, amando, a dos. 


\section{CONCLUSIÓN: CELEBRACiÓN DEL AULA}

Contemplo las filas de estudiantes subiendo por la ladera, los observo distribuyéndose por las distintas escaleras que conducen a los diferentes aularios, me maravillo, una vez más, de ver esa coreografía de cuerpos juveniles dirigiéndose a clase, la misma que se ha repetido durante siglos y que se sigue repitiendo en todas las ciudades del mundo, me pregunto, como cada día, qué busca, o qué espera, si es que espera algo, toda esa muchachada, me pregunto también, y esa pregunta es más difícil, qué es lo que yo busco, lo que espero. Le llamo el momento del desconcierto (Larrosa, 2018, 332-333).

El buen maestro estudia. Lleva consigo una biblioteca que da a leer. Y también da a estudiar. El lugar del exilio del estudioso es el cuarto o el gabinete de estudio; el lugar del encuentro de profesores y alumnos, el aula. Es aquí donde una vocación puede descubrirse. Donde una vida puede cambiar de dirección y sentido. Es algo real y físico. Pero también es un espacio, dicho en el sentido griego del término, espiritual. Allí un estudiante puede encontrarse con la parte de la herencia intelectual y moral que le corresponde por mediación de sus maestros. Decía María Zambrano: "Tienen las aulas su vida propia, abiertas como están y vacías» (Zambrano, 2007, 68). El aula: lugar vacío y dispuesto a llenarse, espacio disponible, dispuesto a ser habitado de continuo. Es un espacio poético, pues en él se da lugar a la presencia entera, plena, de quienes la habitan: profesores, profesoras, jóvenes de ambos sexos. Un espacio dispuesto a la humanidad y a la humanización a través de los saberes que se transmiten, se dialogan, se conversan, leyendo, escribiendo, calculando, pensando.

Se ha sugerido, en distintos contextos, que la defensa de la escuela, hoy, pasa por mantenerla de otro modo; y ese "otro modo" demanda abandonar la idea del aula como centro de lo escolar que, según su interpretación, es una pesada carga decimonónica absolutamente obsoleta e insostenible. Cierto pudor, no obstante, evita que se suprima del todo esta palabra (aula), así que se sugiere una hiperaula en la que varios grupos se reúnen y alternan presencialidad y virtualidad. En fin, el libro -un poco más de lo mismo-, y se insiste en la necesidad de reprofesionalizar al profesor y formarlo para que sea un «diseñador» de los procesos de aprendizaje. En todo caso: "O escuela o aula", pero no las dos cosas juntas.

Estas reivindicaciones me hicieron pensar en otros libros que yo había leído y que me influyeron. Por ejemplo, recordé un viejo ensayo de Michael Oakeshott, donde se dice que la educación

Comienza cuando la transacción se torna «educativa» y cuando aprender se convierte en estudiar para aprender en condiciones en las que se imponen instrucciones y limitaciones, lo que no es casual. Comienza cuando aparece un maestro que tiene algo para impartir que no está relacionado de manera inmediata con las carencias ni con los «intereses» que tiene el estudiante en ese momento (Oakeshott, 2009, 99).

Y también me acordé del libro que escribieron Maarten Simons y Jan Masschelein (Defensa de la escuela. Una cuestión pública) y que yo he leído, comentado, 
pensado y discutido varios años atrás junto a mis alumnos de filosofía de la educación en la Facultad donde imparto mis clases. Lo que dice ese otro libro, que pretende hacernos elegir entre la escuela y el aula, no es, desde luego, sino una manifestación más de algo que Simons y Masschelein dicen en el suyo: el temor y quizá el desprecio hacia un tipo de tiempo libre que la misma escuela produce, y que "transforma los conocimientos y destrezas en "bienes comunes" (Simons y Masschelein, 2014, 12). Ya lo dijo María Zambrano: "El horror de lo que es desinteresado, de lo que en apariencia es nada, llena el ánimo del hombre de nuestro tiempo. Este hombre que cuando se queda solo no sabe en qué pensar, se encuentra empavorecido con un extraño dentro de sí, extraño, ajeno a su propia alma» (Zambrano, 2007, 173).

Esa aversión hacia la escuela tiene muchas variantes y se enmascara de mil maneras. Hace olvidar a algunos que ellos mismos son profesores, un resultado de la escuela misma, y que van a diario a las aulas a enseñarles cosas a sus alumnos; de una aversión que ignora que la escuela forma parte de un "mundo común» (de una visión pública del mundo, ni estrictamente privada ni tampoco social); un mundo con el que nos encontramos al nacer y que dejamos al morir; un mundo que trasciende nuestro tiempo vital, tanto hacia el pasado como hacia el futuro y que compartimos con nuestros contemporáneos, con los que estuvieron antes y con los que llegarán después: «Tal mundo común -decía Arendt- sólo puede sobrevivir al paso de las generaciones en la medida en que aparezca en público» (Arendt, 2005, 75); y esto significa que solo podrá mantenerse si somos capaces -y para esto la escuela fue inventada- de conversarlo entre las generaciones, de leerlo y de estudiarlo incesantemente. La escuela, pues, es un lugar apartado al que se va a aprender mediante el estudio, quizá un lugar donde el heredero puede encontrar su herencia moral e intelectual, aunque «no en los términos en los que se usa en las ocupaciones y los compromisos cotidianos en el mundo exterior» (Oakeshott, 2009, 100).

Si en un momento de la historia la escuela nace, junto al aula ella misma cobija, como un lugar aparte y separado tanto de la familia como de la sociedad; si surge para que profesores y alumnos se ejerciten en el tiempo propio de los hombres libres, y si es cierto que la escuela, poco a poco, y no sin dificultades -entre luces y sombras-, llegó a significar el lugar donde se «estudia al lado de alguien» (Pérez Cortés, 2004, 199), ahora nada de esto tiene ya, al parecer, el menor sentido para los discursos banalizadores de lo escolar que se instalan en ese viejo desprecio hacia la escuela. Desde luego, no hace falta realizar una gran investigación para constatar que los niños y jóvenes que van diariamente a la escuela, desde que ponen un pie en este mundo, viven entre tecnologías, completamente enfrascados en las redes sociales, distraídos y atrapados en la red, que es una tela de araña. Uno se queda perplejo -yo, al menos, me quedo atónito- al leer, una vez más, que la escuela que se propone es lo mismo -idéntico y a su vez clónico-, de lo que esos niños y jóvenes ya saben y dominan a la perfección, porque lo viven a diario. La escuela como extensión de la red (o sea: de lo que se hace en la sociedad, de lo 
que se hace en el seno familiar). Entre el profesor y al alumno no se coloca ya un libro para leer con atención y estudiar, sino una pantalla de ordenador, quizá para que ni profesor ni alumno se miren a la cara y observen sus rostros de profundo aburrimiento y quizá desidia.

El aula, en fin, para este tipo de discursos que pretenden banalizar su importancia, es un topos menor, un lugar donde ya no podemos poner a prueba, ni tampoco ejercitar, ensayar, el oficio de ser un profesor colocando, cosas del mundo, que adoptan la forma de una materia de estudio, de una disciplina, en medio de una relación (la del profesor con sus alumnos). Esa tentativa de ignorar el aula quizá se deba al valor rebajado que hoy la mediación del profesor y del maestro puede llegar a ejercer en la formación de una existencia joven.

Lo que se ha perdido de vista, me temo, es la idea del aula como una disposición y como un êthos o, como decía Heidegger, una Stimmung, un "estado de ánimo", que es, me parece, lo que permite soportar la larga fatiga que padece quien ha de sostenerse, como en este caso, en un quehacer profesoral y estudioso (Heidegger, 2000, 103). Ya nos hemos referido más atrás a la ritualización griega de la entrega del eromenós (joven) al erastés (adulto). En el transcurso de la relación que establecían, el adulto se reencontraba con lo que ya se suponía que tenía: su vocación educadora. La encontraba, precisamente, en el seno de un encuentro con el joven. Para el mundo griego, dejando aparte ahora otros matices, la diferencia de edad (la diferencia misma entre las generaciones) entre ambos resultaba fundamental, pues constituía toda una celebración de la edad adulta, precisamente para que hubiese educación.

Es precisamente ahí donde encuentra un lugar adecuado la vocación pedagógica en la escuela o, para ser más exactos, en la Universidad: en la diferencia de las generaciones, en el encuentro entre tiempos diferentes (tiempo joven y tiempo adulto o tiempo viejo). Es debido a esa diferencia la razón por la cual uno puede, de hecho, hacer resonar en el otro las propias influencias (de maestros y lecturas, por ejemplo) que se han recibido, a la vez como un reconocimiento y como aceptación de una deuda; y es porque esa diferencia existe la razón por la cual uno puede tratar de transmitir al joven la idea de que el mundo no es meramente un jardín privado en el que proyectar narcisísticamente la propia representación que uno tiene de él, para confirmarse incesantemente, sino que, más bien, es lo otro que viene en forma de texto, de libro, de signo que da a pensar, a sentir y a mirar de nuevo.

Por mi parte, cada vez que entro en el aula tengo la sensación de que estoy a punto de dar inicio a uno de mis conciertos. Cuando hablo a los estudiantes y desarrollo algún asunto del programa que he pensado con cuidado, casi artesanalmente -y me lleva mucho tiempo, y se concentra mucho placer y deseo en eso que hago-, tengo la impresión de que al contarles las cosas que cuento también les estoy cantando: modulo el timbre de la voz y la proyecto, y aunque sé que me dirijo a un aula repleta de jóvenes, trato de hablar al oído de cada uno. Hago como si. Sé que no puedo sino tirar flechas al azar. Entro en el aula. Empiezo la clase, todas iguales y distintas entre sí. Me digo a mí mismo que se trata de chicos y chicas 
de poco más de veinte años que estudian Pedagogía. Se supone que quieren saber cosas sobre educación; y aunque no sea verdad, hago como si. Para eso están allí. ¿Cómo, entonces, no hablarles de filosofía?, me pregunto. Me gusta pensar que al entrar en un aula entramos en una Skholè, con todo lo que esto supone. Suelo decirles que esta palabra griega significa en realidad apartamiento o separación del mundo y, por extensión, "Ocio", aunque no cualquier clase de ocio o de "tiempo libre», sino ese tiempo en el que el joven muestra lo mejor de su carácter, desplegando su mejor disposición y manifestando el tipo de ser humano que quiere llegar a ser. Entrar ahí es ponerse a «estudiar».

Cada año escojo los motivos, pienso en la historia que quiero contar a mis alumnos y compartir con ellos. Elijo con cuidado los personajes: los escritores, los filósofos y las filósofas, los poetas y cineastas, los textos. Renuevo mi "Casa de citas»: este documento tiene ahora un centenar de fragmentos o citas. Está compuesto por las obras que me han acompañado a lo largo de mis años de lectura y estudio. Les pido a mis alumnos que las lean, que busquen su cita, la que les pertenece, y que se fijen si quizá la que les está destinada no se encuentra justo al lado de la que están leyendo ahora mismo. Les pido que la habiten durante una semana, que escriban en su diario filosófico, en su cuaderno de mano, y que se dejen llevar. Que se recreen en lo que están leyendo. Y me pregunto: "Pero ¿qué estoy haciendo? ¡No les estoy enseñando a hacer nada! ¿De qué sirve todo esto?».

Vamos leyendo textos y fragmentos de nuestra "Casa de citas». Mezclo fragmentos de filósofos y novelistas. Les insisto otra vez en que escriban en sus diarios, que anoten las cosas que ven. No es un diario íntimo. Es un diario donde, les advierto, "tenéis que recopilar las cosas del mundo: lo que se escucha, lo que se ve, lo que se lee». "¿Pero nos vas a evaluar el diario?", me preguntan. Sonrío: "No, eso no se evalúa. Eso es para vosotros, pero leeremos las entradas que queráis cuando deseéis hacerlo. Es un ejercicio de escritura y de pensamiento. Un cuaderno siempre a mano». Entonces les hablo de Michel Foucault. Les digo que escribió algunos libros muy interesantes y que daba clases en una institución que se llama Collège de France. Leemos en voz alta "La escritura de sí». Una alumna me dice, al terminar el curso, que no ha podido escribir ni una sola línea, y me entrega su cuaderno en blanco, solo con el título: Diario filosófico: bypomnémata. Otros me dicen que, aunque no lo entendían muy bien, les ha gustado escribir, y que creen que hacerlo les ha ayudado, aunque no saben muy bien por qué. Todo esto son situaciones normales y cotidianas.

Preparar una clase o un curso es, para mí, algo muy parecido a preparar un concierto, sí. Hay motivos (canciones) que se repiten, que forman parte de un repertorio ya establecido y, por así decir, clásico; otras son el resultado de nuevas lecturas (canciones nuevas), tentativas de nuevas exploraciones que se ponen a prueba. No puedo evitar celebrar, a través de los textos que leemos, las influencias que yo mismo he recibido, agradecer las lecturas que hice, los encuentros intelectuales que tuve, los músicos que escuché y formaron mi sentido musical. No pretendo que sientan y piensen como yo siento y pienso. Pero del mismo modo que 
haber contemplado, de joven, a mi hermana mayor horas y horas sentada fumando cigarrillos y leyendo novelas de autores franceses e ingleses del siglo XIX hizo que yo amara esa misma literatura; del mismo modo que me aprendí de memoria la letra de Ne me quitte pas, le bellísima canción de Jacques Brel, cuando mi hermana me la leyó en su perfecto francés cuando Brel murió, pienso que, tal vez, la mejor pedagogía es aquella que contamina al otro, no para que él o ella hagan lo que el profesor hace o les dice, sino para que encuentren su propia manera de relacionarse con el mundo y con ellos mismos.

Termino. Un amigo mío muy querido, que me ha influido y puedo considerar en muchos aspectos mi maestro, Jorge Larrosa, me preguntó un día: «¿Cuál es el último capítulo, si lo hay, de una vida de profesor?». Yo le respondí en un largo escrito algunas cosas (lo que acaba de leer el lector o la lectora formaba parte de esa respuesta). En realidad, no supe qué decir a esa última pregunta de Jorge. Pues quizá ese último capítulo sea una penúltima lección, una que el profesor ya no puede dar, porque es una visión que el profesor no contemplará. Es la lección del alumno, del discípulo. Es lo que este verá. Es lo que Dante percibirá, a las puertas de alguna clase de paraíso, pero no Virgilio, el maestro que le ha acompañado durante el trayecto. Es, sí, la desaparición del maestro: su borrado. ¿Será por eso por lo que Nietzsche dijo que se paga mal a un maestro si se permanece siempre discípulo?

\section{REFERENCIAS BIBLIOGRÁFICAS}

AREndt, H. (1996) Entre el pasado y el futuro. Barcelona, Península.

AREndT, H. (2005) La condición humana. Barcelona, Paidós, 2005.

ARISTÓteles (2011) Metafísica. Madrid, Gredos.

ARtières, Ph. y Potte-Bonneville, M. (2012) D'après Foucault. Gestes, Luttes, programmes. París, Éditions Points.

Azorín (1989) La voluntad. Madrid, Clásicos Castalia.

BÁrCena, F. (2016) En busca de una educación perdida. Rosario, Homo Sapiens.

BERnhard, Th. (1987) Maestros antiguos. Madrid, Alianza.

Bloom, H. (2011) Anatomía de la influencia. La literatura como modo de vida. Madrid, Taurus.

Boissinot, A. y Ferry, L. (2017) La plus belle histoire de l'école. París, Robert Laffont.

Bourget, P. (2003) El discípulo. Barcelona, Debate.

Bourget, P. (2010) Le disciple. París, Les Classiques de Poche.

Camus, A. (2003) El primer hombre. Barcelona, Tusquets.

CAmus, A. (2008) Le premier homme. En Oeuvres complètes, IV (1957-1959). París, Bibliothèque de la Pléiade, 741-996.

Chalier, Ch. (1996) L'inspiration du philosophe. París, Albin Michel.

Dardenne, L. (2005) Au dos de nos images, 1991-2005. París, Seuil.

Deleuze, G. (1964) Il a été mon maître. Arts, November 28, 8-9.

Deleuze, G. (1995) Conversaciones. Valencia, Pre-textos.

Deligny, F. (1996) Graine de crapule. París, Éditions du Scarabée.

DERrida, J. (2002) La Universidad sin condición. Madrid, Trotta. 
FarnetTi, C. (ed.) (1998) Gentile-Calogero. Carteggio (1926-1942). Florencia, Le Lettere.

Fernández Enguita, M. (2017) Más escuela y menos aula. Madrid, Morata.

FlaubERT, G. (2009) Querida maestra. Escritoras en la correspondencia de Gustave Flaubert. Córdoba, El Olivo Azul.

Foucault, M. (2001) L’herméneutique du sujet. Cours au Collège de France, 1981-1982. París, Gallimard.

Foucault, M. (2002) La voluntad de saber, en Historia de la sexualidad, I. Buenos Aires, Siglo XXI.

Foucault, M. (2015) Oeuvres, II. París, Bibliothéque de la Pléiade.

GIRARD, R. (1985) Mentira romántica y verdad novelesca. Barcelona, Anagrama.

Gusdorf, G. (1977) ¿Para qué los profesores? Madrid, Edicusa.

HANDKe, P. (1989) Ensayo sobre el cansancio. Madrid, Alianza.

Heidegger, M. (2000) Nietzsche, vol. I. Barcelona, Destino.

HÖrderlin, F. (1995) Poesía completa. Edición bilingüe. Barcelona, Ediciones 29.

JóDAR, F. (2007) Alteraciones pedagógicas. Educación y políticas de la experiencia. Barcelona, Laertes.

LARrosa, J. (2018) Esperando não se sabe o quê. Sobre o oficio de profesor. Belo Horizonte, Autêntica.

Magris, C. (2001) Maestros y alumnos, en Utopía y desencanto. Barcelona, Anagrama, 41-42. MANn, K. (2003) El volcán. Barcelona, Edhasa.

Maquiavelo, N. (2009) Antología. Barcelona, Península.

Marrou, H.-I. (2004) Historia de la educación en la antigüedad. Barcelona, Akal.

Masschelein, J. (2001) The Discourse of the Learning Society and the Loss of Childhood. Journal of Philosophy of Education, 35: 1, 1-20.

Montaigne, M. (2007a) Les Essais. París, Gallimard-Bibliotèque de La Pléiade. Edición a cargo de Jean Basamo, Michel Magnien y Catherine Magnien-Simonin, según la edición de 1595 de Marie de Gournay.

Montaigne, M. (2007b) Los Ensayos. Barcelona, El Acantilado. Edición a cargo de J. Bayod Brau, según la edición de 1595 de Marie de Gournay.

Murdoch, I. (1989) El discípulo del filósofo. Barcelona, Ultramar.

Musil, R. (2003) Las tribulaciones del estudiante Törless. Madrid, Siruela.

NieTzSCHE, F. (1996) Schopenhauer como educador, en Schopenhauer como educador y otros textos. Barcelona, Círculo de Lectores, 139-224. Traducción de Andrés Sánchez Pascual.

Nietzsche, F. (2009) Así habló Zaratustra. Madrid, Alianza.

OAKESHOTT, M. (2009) La educación: el compromiso y su frustración, en La voz del aprendizaje liberal. Buenos Aires, Katz Editores.

ORdine, N. (2017) Clásicos para la vida. Una pequeña biblioteca ideal. Barcelona, El Acantilado.

Pasolini, P. P. (2010) Cartas luteranas. Madrid, Trotta.

Pennac, D. (2008) Mal de escuela. Barcelona, Mondadori.

PEREC, G. (2014) W, o el recuerdo de la infancia. Palencia, Menos cuarto.

PÉrez Cortés, S. (2004a) Palabras de filósofos. Oralidad, escritura y memoria en la filosofía antigua. Buenos Aires, Siglo XxI editores.

PÉrez Cortés, S. (2004b) Palabras de filósofos. Oralidad, escritura y memoria en la filosofía antigua. México, Siglo XxI Editores.

Platón (1997) Diálogos, vol. iII: Fedón, Banquete, Fedro. Madrid, Gredos.

RANCIÈRE, J. (2002) El maestro ignorante. Barcelona, Laertes. 
Recalcati, M. (2014) El complejo de Telémaco. Padres e hijos tras el ocaso del progenitor. Barcelona, Anagrama.

Recalcati, M. (2016) La hora de clase. Por una erótica de la enseñanza. Barcelona, Anagrama. Romilly, J. (1991) Écrits sur l'enseignement. París, Éditios de Fallois.

Roth, Ph. (2012) El profesor del deseo. Barcelona, Debolsillo.

SCHLANGER, J. (1997) La vocation. París, Seuil.

Schopenhauer, A. (2009) Sobre la filosofía universitaria, en Parerga y Paralipómena. Madrid, Valdemar, 161-222. Traducción de J. Rafael Hernández Arias.

SENNET, R. (2009) El artesano. Barcelona, Anagrama.

SHelley, M. (2006) Frankenstein o el moderno Prometeo. Barcelona, Mondadori.

Simons, M. y Masschelein, J. (2014) Defensa de la escuela. Buenos Aires, Miño \& Dávila.

STABILE, A. (1988) I buoni mestri. Milan, Mondadori.

SteinBeck, J. (2009) Al este del Edén. Barcelona, Tusquets.

STEINER, G. (2003) Lecciones de maestros. Madrid, Siruela.

WALSER, R. (1998) Jakob von Guten. Madrid, Siruela.

WANQUET, F. (2008) Les enfants de Socrate. Filiation intellectuelle et transmission du savoir $X V I I^{e}-X X I^{e}$ siècle. París, Albin Michel.

Williams, J. (2015) Stoner. Tenerife, Baile del Sol.

Zambrano, M. (2007) Filosofía y educación. Manuscritos. Málaga, Editorial Ágora.

Zorn, F. (2009) Bajo el signo de Marte. Barcelona, Anagrama.

ZweIG, S. (2014) Confusión de sentimientos. Barcelona, El Acantilado. 